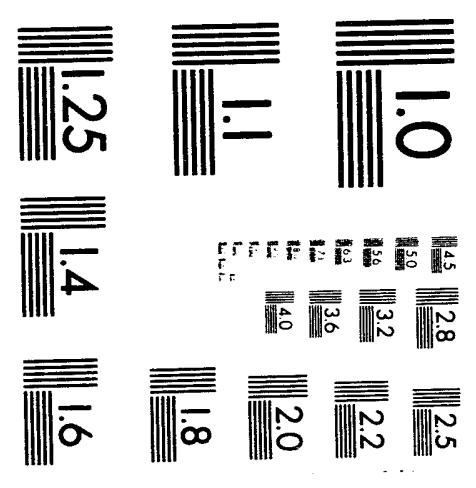

.

.

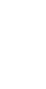




\section{Waste Isolation Pilot Plant}

\section{Land Management Plan}

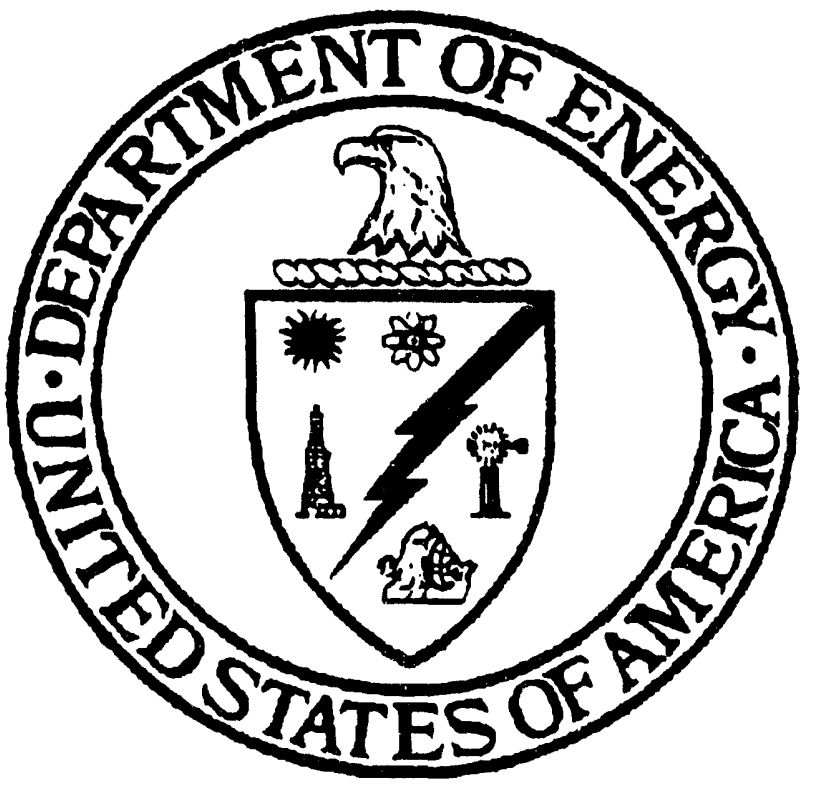

Waste Isolation Pilot Plant MASTER 


\section{TABLE OF CONTENTS}

\section{Waste Isolation Pilot Plant Land Management Plan DOE/WIPP 93-004}

Acronyms and Abbreviations $\ldots \ldots \ldots \ldots \ldots \ldots \ldots \ldots$ vi

Preface $\ldots \ldots \ldots \ldots \ldots \ldots \ldots \ldots \ldots \ldots \ldots \ldots \ldots$ vii

\section{CHAPTER 1}

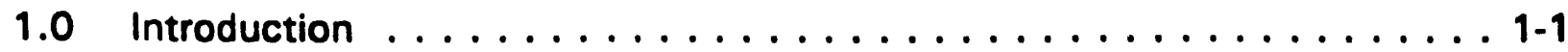

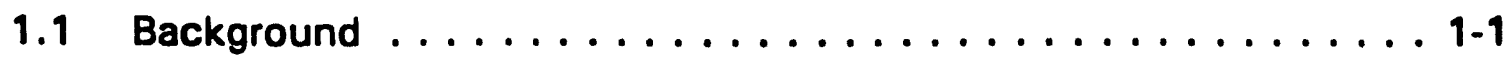

1.2 Management Goal . . . . . . . . . . . . . . . . 1-5

\section{CHAPTER 2}

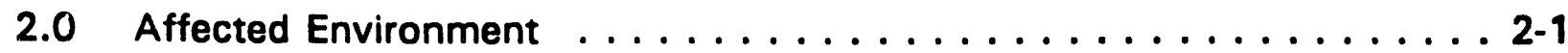

2.1 Affected Wildlife Environment . . . . . . . . . . 2-2

2.2 Affected Biological Environment . . . . . . . . . . . 2-4

2.3 Cultural Resources in the Affected Environment . . . . . . . 2-5

2.4 Affected Grazing Environment . . . . . . . . . . . 2-8

2.5 Recreation within the Affected Environment . . . . . . . . 2-11

2.6 Access into the Affected Environment . . . . . . . . . 2-11

2.7 Emergency/Security within the Affected Environment . . . . 2-12

2.8 Affected Socioeconomic Environment . . . . . . . . . . 2-12

2.9 Water Service Pipeline within the Affected Environment . . . . . 2-13

2.10 Groundwater Surveillance within the Affected Environment . . 2-13

2.11 Salt Tailings within the Affected Environment . . . . . . . . 2-13

2.12 Air Quality in the Affected Environment . . . . . . . . . . 2-14

2.13 Sewage Lagoon within the Affected Environment . . . . . . 2-15

2.14 Reclamation of the Affected Environment . . . . . . . 2-16

2.15 Critical Elements of the Environment . . . . . . . . . 2-16 


\section{TABi E OF CONTENTS (continued)}

\section{CHAPTER 3}

3.0 Management Objectives and Planned Actions $\ldots \ldots \ldots \ldots$ 3-1

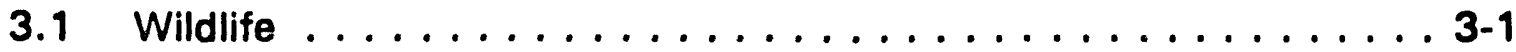

3.1.1 Objective $\ldots \ldots \ldots \ldots \ldots \ldots \ldots \ldots \ldots \ldots \ldots$ 3-1

3.1.2 Planned Actions $\ldots \ldots \ldots \ldots \ldots \ldots \ldots \ldots$ 3-1

3.1.3 Special Status Species $\ldots \ldots \ldots \ldots \ldots \ldots \ldots$. . . . . . .

3.1.3.1 Objective .............. 3-2

3.1.3.2 Planned Actions . . . . . . . . . . 3-2

3.1.4 Wildlife Habitat $\ldots \ldots \ldots \ldots \ldots \ldots \ldots \ldots . \ldots . . . \ldots .2$

3.1.4.1 Objective $\ldots \ldots \ldots \ldots \ldots \ldots \ldots \ldots .2$

3.1.4.2 Planned Actions . . . . . . . . . 3.3

3.2 Cultural Resources $\ldots \ldots \ldots \ldots \ldots \ldots \ldots \ldots \ldots \ldots$.4

3.2.1 Objectives $\ldots \ldots \ldots \ldots \ldots \ldots \ldots \ldots \ldots \ldots \ldots . \ldots \ldots$

3.2.2 Planned Actions $\ldots \ldots \ldots \ldots \ldots \ldots \ldots \ldots . \ldots .4$

3.3 Grazing Management $\ldots \ldots \ldots \ldots \ldots \ldots \ldots \ldots \ldots$ 3-5

3.3.1 Objective $\ldots \ldots \ldots \ldots \ldots \ldots \ldots \ldots \ldots \ldots \ldots \ldots$ 3-5

3.3.2 Planned Actions $\ldots \ldots \ldots \ldots \ldots \ldots \ldots . \ldots . \ldots . \ldots . \ldots$

3.4 Recreation ......................... 3-7

3.4.1 Objective $\ldots \ldots \ldots \ldots \ldots \ldots \ldots \ldots \ldots \ldots \ldots \ldots \ldots$

3.4.2 Planned Actions $\ldots \ldots \ldots \ldots \ldots \ldots \ldots \ldots . \ldots . . \ldots$. . . . . . .

3.4.3 Outdoor Recreation Management . . . . . . . . . . 3-8

3.4.3.1 Objective $\ldots \ldots \ldots \ldots \ldots \ldots \ldots . . \ldots \ldots$

3.4.3.2 Planned Actions . . . . . . . . . . 3-8

3.4.4 Hunting and Trapping . . . . . . . . . . . . . 3-8

3.4.4.1 Objectives . . . . . . . . . . . . 3-8

3.4.4.2 Planned Actions . . . . . . . . . . . 3.8

3.4.5 Off-Road Vehicle Designations . . . . . . . . . . . 3-9

3.4.5.1 Objectives . . . . . . . . . . . 3-9

3.4.5.2 Planned Actions . . . . . . . . . . . . 3-9 
3.4.6 Visual Resources Managernent . . . . . . . . 3-10 3.4.6.1 Objectives . . . . . . . . . . 3-10

3.4.6.2 Planned Actions . . . . . . . . . . . . 3-10

3.5 Mining and Oil and Gas Production . . . . . . . . . . . 3-10

3.5.1 Objective $\ldots \ldots \ldots \ldots \ldots \ldots \ldots \ldots \ldots \ldots$ 3-10

3.5.2 Planned Actions $\ldots \ldots \ldots \ldots \ldots \ldots \ldots$ 3-11

3.6 Rights-of-Way . . . . . . . . . . . . . . 3-13

3.6.1 Objective .................... 3-13

3.6.2 Planned Actions $\ldots \ldots \ldots \ldots \ldots \ldots \ldots \ldots$. . . . . . . . .

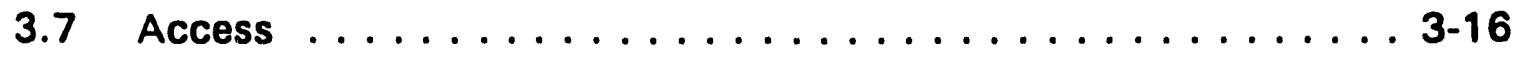

3.7.1 Objective $\ldots \ldots \ldots \ldots \ldots \ldots \ldots \ldots \ldots \ldots \ldots \ldots$ 3-16

3.7.2 Planned Actions $\ldots \ldots \ldots \ldots \ldots \ldots \ldots \ldots$. . . . . . . . . . . .

3.8 Emergency and Facility Security $\ldots \ldots \ldots \ldots \ldots \ldots \ldots \ldots$ 3-19

3.8.1 Objective $\ldots \ldots \ldots \ldots \ldots \ldots \ldots \ldots \ldots$ 3-19

3.8.2 Planned Actions $\ldots \ldots \ldots \ldots \ldots \ldots \ldots \ldots \ldots$. . . . . . . . .

3.9 Fire Management $\ldots \ldots \ldots \ldots \ldots \ldots \ldots \ldots \ldots \ldots$. . . . . . . . . .

3.9.1 Objective $\ldots \ldots \ldots \ldots \ldots \ldots \ldots \ldots \ldots \ldots \ldots . . \ldots \ldots$

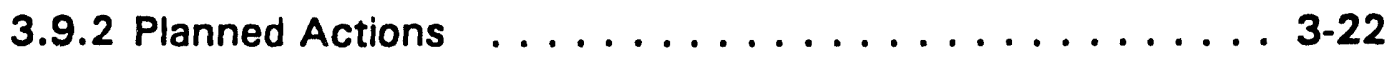

3.10 Water Service Pipeline . . . . . . . . . . . . . . . . . . 3-22

3.10.1 Objective $\ldots \ldots \ldots \ldots \ldots \ldots \ldots \ldots \ldots \ldots \ldots .22$

3.10.2 Planned Actions . . . . . . . . . . . . 3-24

3.11 Groundwater Surveillance . . . . . . . . . . . . . . . . 3-24

3.11.1 Objective . . . . . . . . . . . . . . 3-24

3.11.2 Planned Actions . . . . . . . . . . 3-27

3.12 Salt Tailings . . . . . . . . . . . . . . . . 3-28

3.12.1 Objective $\ldots \ldots \ldots \ldots \ldots \ldots \ldots \ldots \ldots \ldots \ldots$

3.12.2 Planned Actions . . . . . . . . . . 3-28 
TABLE OF CONTENTS (continued)

3.13 Reclamation ...................... 3-30

3.13.1 Objective $\ldots \ldots \ldots \ldots \ldots \ldots \ldots \ldots \ldots$ 3-30

3.13.2 Planned Actions . . . . . . . . . 3-30

\section{APPENDIX A}

Consultation and Coordination $\ldots \ldots \ldots \ldots \ldots \ldots \ldots \ldots \ldots$ A-1

APPENDIX B

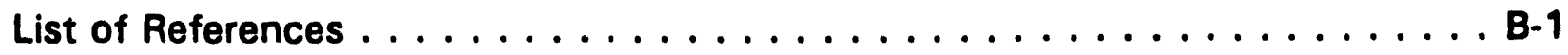




\section{LIST OF FIGURES}

Figure

Title

Page

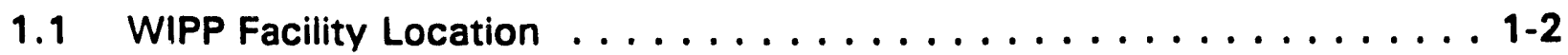

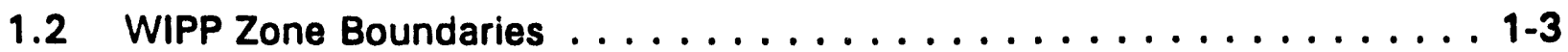

1.3 WIPP Withdrawal Site, Eddy County, New Mexico . . . . . . . . . . . 1-4

2.1 Grazing Allotment Boundaries Within the Withdrawal Area . . . . . . 2-9

3.1 Oil and Gas Leases in Section 31 of the WIPP Land Withdrawal Area . 3-12

3.2 Rights-of-Way for the WIPP $\ldots \ldots \ldots \ldots \ldots \ldots \ldots \ldots \ldots \ldots$ 3-15

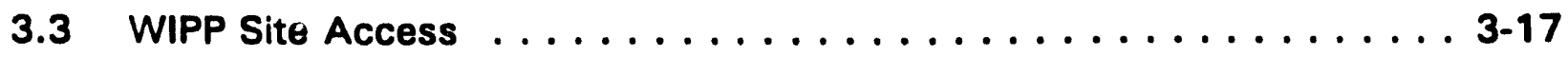

3.4 WIPP Facility Boundaries . . . . . . . . . . . . . . 3-20

3.5 Groundwater Surveillance Wellbores . . . . . . . . . . . 3-26

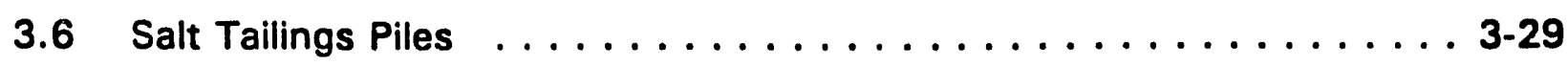




\section{ACRONYMS AND ABBREVIATIONS}

ACA Agency for Conservation Archaeology

Act Waste Isolation Pilot Plant Land Withdrawal Act

ATSF Atchison, Topeka, and Santa Fe

AUM Animal Unit Months

BLM Bureau of Land Management

DOE Department of Energy

EMNRD (New Mexico) Energy, Minerals, and Natural Resources Department

FEIS Final Environmental Impact Statement

FRCD Forestry \& Resources Conservation Division of EMNRD

FSEIS Final Supplement Environmental Impact Statement

FLPMA Federal Land Policy and Management Act

HPD Historic Preservation Division of OCA

MOU Memorandum of Understanding

NEPA National Environmental Policy Act

NMDG\&F New Mexico Department of Game and Fish

NMED New Mexico Environment Department

OCA (New Mexico) Office of Cultural Affairs

OCD Oil Conservation Division of EMNRD

ORV Off-road vehicles

RCRA Resource Conservation and Recovery Act

RMP Resource Management Plan

SHPO (New Mexico) State Historical Preservation Officer

SLO (New Mexico) State Land Office

SPDV Site and Preliminary Design Validation

USFWS United States Fish and Wildlife Service

WIPP Waste Isolation Pilot Plant

WPSO WIPP Project Site Office 


\section{PREFACE}

To reflect the requirement of section 4 of the Waste Isolation Pilot Plant Land Withdrawal Act (the Act) (Public Law 102-579), this land management plan has been written for the withdrawal area consistent with the Federal Land Policy and Management Act of 1976. This land management plan has been prepared by the U.S. Department of Energy (DOE) in consultation with the U. S. Department of Interior, Bureau of Land Management (BLM), and the State of New Mexico. In accordance with the Act, it will be submitted to the Congress and the State of New Mexico. Any amendments to this plan will be developed in consultation with the BLM and the State of New Mexico and promptly submitted to the Congress and the State.

The objective of this document, per the Act, is to describe the plan for the use of the withdrawn land until the end of the decommissioning phase. The plan identifies resource values within the withdrawal area and promotes the concept of multiple-use management. The plan also provides opportunity for participation in the land use planning process by the public and local, State, and Federal agencies.

As a complement to this land management plan, a memorandum of understanding (MOU) will be executed between the DOE and the BLM, as required by section $4(d)$ of the Arit. The MOU will serve to outline responsibilities of each agency with regard to addressing land use management for the withdrawal area. The MOU also will serve as an additional mechanism to provide protection of the withdrawal area from unallowable or inadvertent uses. The State of New Mexico will be consulted in developing the MOU and the associated statement of work.

Though not specifically mandated by the Act, the DOE recognizes significant advantage in developing a formal relationship with the State of New Mexico regarding land management. DOE will attempt to enter into a MOU or other agreement with the State of New Mexico in this regard. This document could outline specific responsibilities of the parties with regard to addressing WIPP land management topics of mutual interest and protocols to be followed. 
A WIPP Land Management Implementation Plan, an internal document which formalizes standard practices, will be written in consultation with the State of New Mexico to provide guidance in areas involving the management and oversight for the withdrawn land and other lands used in the operation of the WIPP, (e.g. groundwater surveillance well pads outside of the withdrawn area). This plan will address compliance and regulatory and statutory requirements applicable to activities that occur on or are pertinent to WIPP controlled lands through solicitation of recommendations and guidance by affected local, State, and Federal agencies.

The format used in writing this plan parallels the general guidelines used in the formulation of the BLM's Carlsbad Resource Management Plan.

This land management plan will be reviewed on a biennial basis to assess the document's adequacy and effectiveness, or as may be necessary to address emerging issues potentially affecting the withdrawal area. Affected Government and State agencies will be involved in this review process.

Chapter 1, Introduction, provides the reader with the purpose of this land management plan as well as an overview of the Waste Isolation Pilot Plant. Chapter 2. Affected Environment, is a brief description of the existing resources within the withdrawal area. Chapter 3, Management Objectives and Planned Actions, describes the land management objectives and actions taken to accomplish these objectives. 


\section{CHAPTER 1}

\subsection{INTRODUCTION}

\subsection{Backaround}

The Waste Isolation Pilot Plant (WIPP) facility, a project of the United States Department of Energy (DOE), is authorized by Public Law 96-164 to provide a research and development facility to demonstrate the safe disposal of radioactive wastes resulting from the defense activities and programs of the United States.

The WIPP site is located in Eddy County in southeastern New Mexico (Figure 1.1). The site is $\mathbf{2 6}$ miles east of Carlsijad in an area known as Los Medaños (which translates to "the dunes"), on a relatively flat, sparsely inhabited plateau with little surface water and limited land uses. The land is primarily used for grazing. Other land uses within five miles of the WIPP site boundary include potash mining and oil and gas exploration and development.

Areas that have been designated as subdivisions within the WIPP site boundary include Zones $I$ and II. Zone $I$ is an area of 35 acres surrounded by a chain link fence. Most of the WIPP facility surface structures are located within this area. Zone II is the area that overlies the maximum extent of underground development. The WIPP site boundary provides a minimum of a one mile wide buffer area of intact salt around Zone II (Figure 1.2).

On October 30, 1992, the Act was signed into law. The Act transferred responsibility for management of the WIPP withdrawal, comprised of 10,240 acres within T. 22 S., R. 31 E., Sections 15, 16, 17, 18, 19, 20, 21, 22, 27, 28, 29, 30, 31, 32, 33 , and 34 (Figure 1.3), from the Secretary of the Interior to the Secretary of Energy. 


\section{WIPP FACILITY LOCATION}

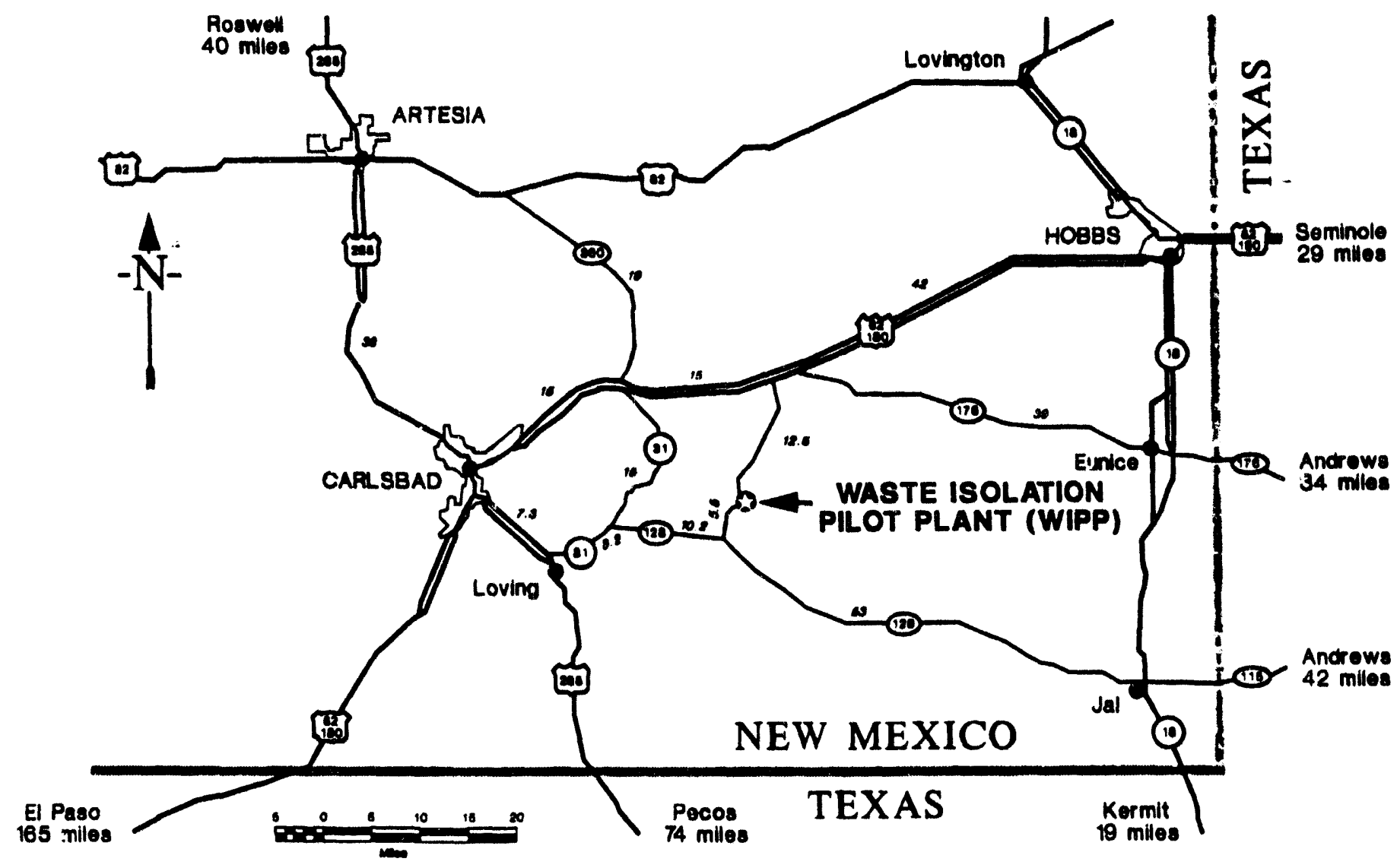

Figure 1.1 


\section{WIPP ZONE BOUNDARIES}

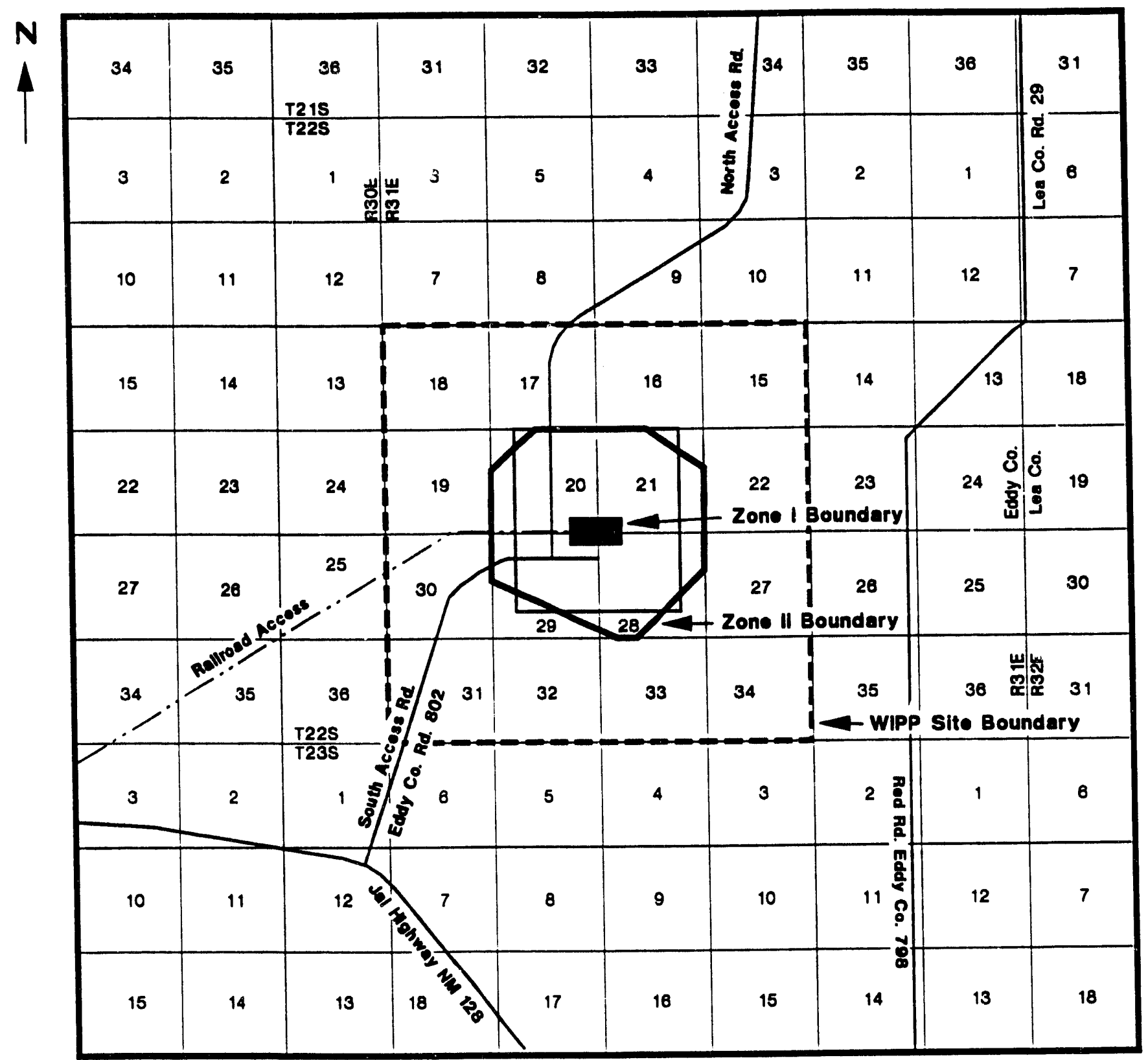

Figure 1.2 


\section{WIPP WITHDRAWAL SITE EDDY COUNTY, NEW MEXICO}

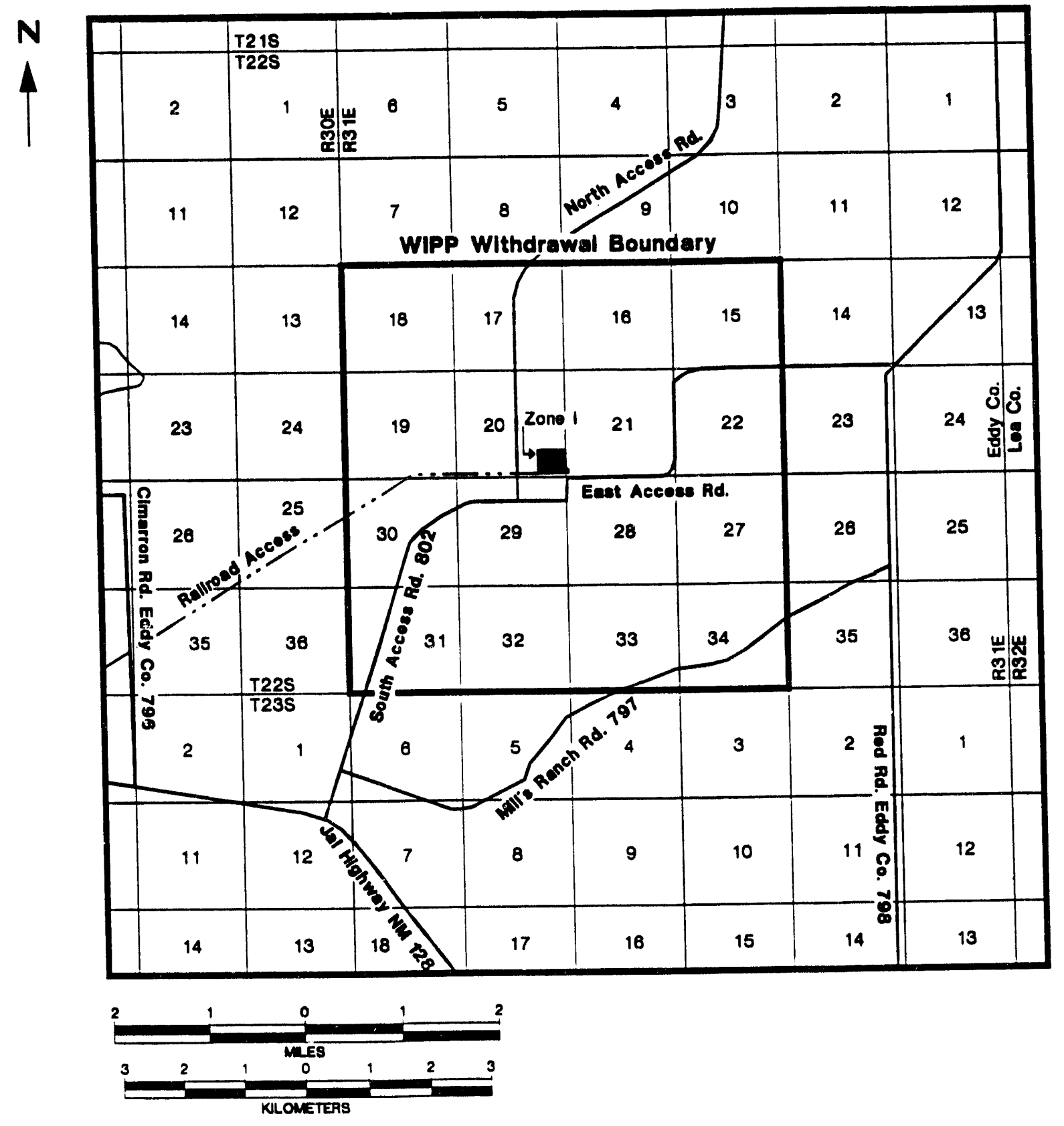

Figure 1.3 
In accordance with sections $3(a)(1)$ and (3) of the Act, these lands are withdrawn from all forms of entry, appropriation, and disposal under the public land laws, and are reserved for the use of the Secretary of Energy for the construction, experimentation, operation, repair and maintenance, disposal, shutdown, monitoring, decommissioning, and other authorized activities associated with the purposes of the WIPP.

Section $4(b)(1)$ of the Act requires the preparation of a land management plan by October 30, 1993. This WIPP Land Management Plan, prepared by the DOE in consultation with the BLM and the state of New Mexico, fulfills this requirement. This land management plan is, and the future management of the withdrawal area will be, consistent with the Federal Land Policy and Management Act of 1976 (FLPMA), the WIPP Land Withdrawal Act, and other applicable laws. The term of this land management plan is through the decommissioning of the WIPP facility. In accordance with the Act, the plan will be submitted to the Congress and the State of New Mexico, and any amendments to this plan will be promptly submitted to the Congress and the State. Section 13(b) of the Act requires a separate plan for the management and use of the withdrawal area following the decommissioning of the WIPP or the termination of the land withdrawal.

\subsection{Management Goal}

The goal of this land management plan is to manage the surface of the withdrawal area under the traditional public land use concept of multiple use and to minimize, to the extent possible, land use restrictions. It is not the intent of the DOE to manage the surface of the withdrawal area as a WIPP exclusive-use area. The subsurface of the withdrawal area is restricted to exclusive use by the WIPP, except for two 320-acre tracts of land within the withdrawal area that are leased for oil and gas development below 6000 feet (Federal Oil and Gas Leases No. NMNM 02953 and No. NMNM 02953C). This restriction is needed to protect the long-term integrity of the WIPP repository. In addition, it is clearly the intent of DOE that during repository operations, facility safety and security shall be maintained. 
In accordance with section 4 (c) of the Act, if during the land withdrawal the Secretary determines, in consultation with the Secretary of the Interior, that the health and safety of the public or the common defense and security require the closure to the public of any road, trail, or other portion of the withdrawal area, the DOE will take whatever action the Secretary determines to be necessary to effect and maintain the closure and shall provide notice to the public of such closure.

Any amendment to this plan will be developed in consultation with the BLM and the State of New Mexico and promptly submitted to the Congress and the State as required by section $4(e)$ of the Act. 


\section{CHAPTER 2}

\subsection{AFFECTED ENVIRONMENT}

This section will provide a brief description of the existing resources within the withdrawal area.

The following area within the withdrawal is inclusive of the affected environment; however, it has been closed to the public as a designated "Off-Limits Area."

The "Off-Limits Area" of 300 acres within Sections 20, 21, 28, and 29 of T. 22 S., R. 31 E., is surrounded by a five-strand barbed wire fence. The fenced area is posted against trespass under the authority of $\$ 229$ of the Atomic Energy Act, 42 U.S.C. 2278a, and pursuant to the regulations set forth in 10 CFR 860 and DOE Order 5632.6, "Physical Protection of DOE Property and Unclassified Facilities."

The DOE intends to expand the posted area to include 1,454 acres within Sections $20,21,28$, and 29 of T. 22 S., R. 31 E., in order to better ensure the security of the premises and the safety of persons present at the WIPP facility. The expanded area would be posted against trespass under the authority of $\$ 229$ of the Atomic Energy Act, 42 U.S.C. 2278a, and pursuant to the regulations set forth in 10 CFR 860 and DOE Order 5632.6, "Physical Protection of DOE Property and Unclassified Facilities." While it would be posted, the expanded area would not be fenced.

Other critical elements (subject to requirements specified in statute, regulation, or executive order) have been evaluated and are either not present or are not affected by the withdrawal. These elements are addressed in the section entitled "Critical Elements of the Environment." 


\subsection{Affected Wild life Environment}

Wildlife in the area is characterized by species of insects, amphibians, reptiles, birds, and mammals. The Jerusalem cricket (Stenopelmatus fuscus) is one example of many different orders of the class Insecta identified in the area. Amphibians are represented by no fewer than ten different species, which include red-spotted toads (Bufe punctatus), Texas toads (Bufo speciosus), Couch's spadefoot toads (Scaphiopus couchi), plains spadefoot toads (Spea bombifrons), New Mexico spadefoot toads (Spea hammondi), and western tiger salamanders (Ambystoma tigrinum) (C. Painter, NMDG\&F pers. comm.). As with most desert amphibians, these are rarely seen until spring or summer rains, at which time they appear in considerable numbers.

Reptiles comprise the more conspicuous inhabitants due to the diurnal activities of many of the species. The vicinity of the WIPP site hosts over 35 different species of reptiles. Ornate box turtles (Terrapene ernata), leopard lizards (Gambelia wislizeni), collared lizards (Crotaphytus collaris), desert side-blntched lizards (Uta stansburiana), whiptail lizards (Cnemidophorus spp.), Round-tailed lizards (Phrvnosoma modestum), Texas horned lizards (Phrynosoma cornutum, a federal notice-of-review species for listing under the Endangered Species Act), great plains skinks (Eumeces obsoletus), western diamondbacked and prairie rattlesnakes (Crotalus spp.), western hognose snakes (Heterodon nasicus), New Mexico milk snakes (Lampropeltis trianqulum celaenoos), and desert king snakes (Lampropeltis getula splendida) are a few examples of the reptile community of Los Medaños.

Various species of birds inhabit the area either as transients or year-long residents. Mourning doves (Zenaida macroura), loggerhead shrikes (Lanius ludovicianus), pyrrhuloxias (Cardinalus sinuata), black-throated sparrows (Amphispiza bilineata), plains bobwhite quail (Colinus virginianus tavlori), scaled quail (Callipepla squamata), and the lesser prairie chicken (Tympanuchus pallidicinctus) are examples of species frequently observed in the area. Migrating or breeding waterfowl species are not considered common in the area. The area supports a large and diverse population of raptors. Species such as Harris' hawks (Parabuteo unicinctus), Swainsons' hawks (Buteo 
swainsonil, and great horned owls (Bube virginianus) illustrate species which are commonly found nesting in the area. The density of large avian-predator nests has been documented as among the highest in recorded scientific literature (Hayden and Bednarz 1988).

The most conspicuous mammals in the area are the black-tailed jackrabbit Lepus californicus) and the desert cottontail (Sylvilaqus audoboni). Common small mammals found in the vicinity of the WIPP site include Ord's kangaroo rat (Dipodomys ordii), plains wood rat (Neotoma micropus), spotted ground squirrel (Spermophilus spilosoma), plains pocket mouse (Perognathus flavescens), the northern grasshopper mouse (Onvchomvs leucogaster), and the brush mouse (Peromyscus boylei). Big-game species, such as the mule deer (Odecoileus hemionus) and the pronghorn (Antilocarpa americana), and carnivores, such as the coyote (Canis latrans) and the badger (Taxidea taxis), are present in smaller numbers.

The DOE consulted with the U.S. Fish and Wildlife Service (USFWS) in 1979 to determine the presence of threatened and endangered species at or near the WIPP site. At that time, the USFWS listed the Lee pincushion cactus (Coryphantha sneedi var. leej), the black-footed ferret (Mustela nigripes), the American peregrine falcon (Falco perearinus anatum), and the bald eagle (Haliaeetus leucocephalus) as threatened or endangered and having the potential to occur on lands within or outlying the WIPP site. In 1989, the DOE again consulted with the USFWS to update this list of threatened or endangered species. The USFWS advised the DOE that the list of species provided in 1979 is still valid except that the black-footed ferret (Mustela nigripes) should now be deleted. The DOE believes that the activities that will take place at WIPP will have no impact on any threatened or endangered species, as documented in the Final Supplement Environmental Impact Statement (FSEIS), January 1990, and the Final Environmental Impact Statement (FEIS), October 1980. In addition, there is no critical habitat for terrestrial species identified as endangered by either the USFWS or the New Mexico Department of Game and Fish (NMDG\&F) within the withdrawal area. 
Also in 1989, the DOE consulted with the New Mexiro Department of Game and Fish (NMDG\&F) regarding the state-listed endangered species in the vicinity of the WIPP site. The NMDG\&F currently lists (based on NMDG\&F Regulation 657, dated January 9, 1988 ) seven birds and one reptile, dunes sagebrush lizard (Sceloporus graciosus arenicolous), that are in one of two endangerment categories and have the potential to occur on lands within or outlying the WIPP site. The NMDG\&F agreed that the proposed WIPP activities would probably not have appreciable impacts on state-listed species in the area (NMDG\&F 1989).

\subsection{Affected Biological Environment}

The WIPP site is located in the northern region of the Chihuahuan desert in an area characterized by large, stabilized sand dunes. The close proximity of the Los Medaños to the Llano Estacado, or "staked plains," provides for a blend of plant and animal communities.

Indigenous plant communities are dominated by Havard shinnery oak lQuercus havardii), mesquite (Prosopis glandulosa), sand sage (Artemesia fillifolia), plains yucca (Yucca campestris), narrowleaf and broom snakeweed (Gutierrezia spp.), sunflower (Helianthus spp.), southwest rabbit brush (Chrysothamnus pulchellus), dropseeds (Sporobolus spp.), 3-awns (Aristida spp.), bluestems (Andropogon spp.), and numerous other species of forbs and grasses. Typically, these plants are regarded as either drought tolerant or drought resistant. Dominant shrubs of the area are usually deep-rooted species with intricate root systems conducive to subsisting in the unpredictable desert environment. Desert plants not only stabilize the dune sand but serve as food, shelter, and nesting habitat for the wildlife which inhabits the area. To date, over 800 different species of plants have been identified in the Chihuahan desert, more than 100 of which occur within the land withdrawal area. Inventery of Rare and Endangered Plants of New Mexice (EMNRD 1993L, which lists the plants in New Mexico classified as threatened, endangered, or sensitive, includes 20 species, representing 14 families, that are found in Eddy County and could occur at or near the WIPP site. 


\subsection{Cultural Besources in the Affected Environment}

From man's first arrival in the Southwest about 10,000 B.C. to the late 1800s, southeastern New Mexico was inhabited by aboriginal hunters and gatherers who subsisted on various wild plants and animals. These people would have found a number of edible plants throughout the region, including mesquite beans, hackberries, walnuts, acorns, seed-producing grasses, agave, and a variety of other succulents. Big and small game, including bison, deer, antelope, rabbits, reptiles, birds, and various invertebrates, could have been hunted or collected in the region.

From about 600 A.D. onward, as trade networks were established with Puebloan peoples to the west, domesticated plant foods and materials, including corn or maize, beans, squash, and cotton, were acquired in exchange for dried meat, hides, and other products from the Pecos Valley and Plains. The indigenous population may also have practiced horticulture at favorable locales in the area, but only on an intermittent basis, since water for crops would have been scarce and unpredictable much of the time.

In the mid-1500s, the Spanish Conquistadors encountered Jumano and Apachean peoples in the region practicing hunting and gathering and engaging in trade with Puebloans. Later, as the natives acquired horses and as Europeans began settling the land, this traditional way of life evolved into specialized bison hunting on the Llano Estacado and raiding both Spanish and Puebloan settlements to the west. In the late 1800 s, the region was settled by ranchers and farmers.

The WIPP withdrawal area is situated in dune-covered, rolling-plains terrain in the eastern part of the BLM's Carlsbad Resource Area. Known archeological sites within the area are primarily the remains of prehistoric camps and short-term settlements. These localities are generally marked by hearth features, scattered burned rock, flaked stone projectile points and cutting and scraping tools, pottery fragments, and groundstone implements. These locations represent short-term, probably seasonal occupations by small, nomadic groups of hunters and gatherers who utilized the plants and animals in the dune lands east of the Pecos River. In a few cases within the withdrawal area, sites 
with evidence of structures have been reported. These sites probably hosted occupations of perhaps several weeks or months.

Historical sites known in southeastern New Mexico consist primarily of early twentieth century homesteads that falled, or isolated features from late nineteenth and early twentieth century cattle or sheep ranching and military activities. Although the region was part of the Spanish and Mexican colonial empires, no related conquest or settlement sites have yet been identified.

Historic components (more than 50 years old) are rare but are occasionally noted for the withdrawn area. These include features and debris related to ranching in the early years of the twentieth century. In addition, more modern ranching debris and facilities such as fence lines are present in the area, including some which are likely still in use. Ranch-related sites which date to the 1940s and 1950s are common in parts of the withdrawn area. These will be considered historical properties within the next several years and under current law will have to be treated as such. The majority of the several sites recorded in the area typically include elements which can contribute to their eligibility for the National Register of Historic Places. With few exceptions, cultural properties known or anticipated for the withdrawal area are significant; and they must be identified, recorded, assessed through inventory, and considered in any plan of development for the area.

Compared with most other parts of southeastern New Mexico, the locations and nature of cultural resources within the WIPP withdrawal area can be described relatively well, based on intensive inventory of portions of the area, along with limited excavation and other work on some sites.

In 1976 four sections comprising the WIPP core area (Sections 20, 21, 28, and 29), along with associated rights-of-way and drilling pads within and outside the withdrawal area (Nielsen 1976; Linnabery 1976), were inventoried by the Agency for Conservation Archaeology (ACA) of Eastern New Mexico University. Additional rights-ofway within and outside the withdrawal area were inventoried in 1978 and 1979 by ACA 
(Schermer 1978; MacLennan and Schermer 1979). Sites identified within the core area were relocated and evaluated in 1980 by ACA, and management recommendations for those sites were prepared (Schermer 1980). Subsequently, in accordance with the ACA's recommendations, a number of sites within the WIPP core area were tested for eligibility and/or were excavated as mitigation (Hicks 1981a; 1981b; Lord and Reynolds 1985).

In 1987 Mariah Associates conducted an intensive study of portions of 45 sections surrounding the WIPP facility. Mariah's study included an inventory of 2,460 acres in 15 quarter-section units. Inventoried units were selected 80 as to be representative of the area as a whole. Within each of the sample units, all cultural resource sites encountered were recorded, certain selected sites were tested, and management recommendations were prepared (Mariah Associates, 1987).

Between 1989 and 1992, several seismic projects associated with oil and gas development provided cultural resource clearances within the withdrawal area (Hunt 1992a; 1992b; Hunt and Martin 1989; 1991; Martin 1992). Numerous additional inventories have been conducted outside the withdrawal area, primarily for oil and gas exploration and ranching.

Inventories conducted to date within the withdrawal area have located 59 archeological sites, along with 91 isolated occurrences (single or few artifacts, or isolated features which can be fully recorded in the field). Sites and isolates identified are almost exclusively prehistoric. Only one site with both prehistoric and historic components has been noted.

Of a total of 10,240 acres in the withdrawal area, 3,830 acres (37 percent) have been inventoried for cultural resources. The results have been the discovery of one site for every 65 acres surveyed, and one isolate in every 42 acres. Based on this information, and assuming environmental homogeneity and a fairly even distribution of sites, the remaining 6,410 uninventoried acres could contain approximately 99 sites and 153 isolates. The combined results of the several inventories conducted within the 
withdrawal area compare well with those from Mariah's 1987 inventory of selected units over a much larger area. Mariah's results show only a slightly higher frequency of cultural resources per acre. In 2,460 acres, 40 sites and 75 isolates were recorded, or one site for every 62 acres and one isolate in every 33 acres.

Of the $\mathbf{4 0}$ sites identified and evaluated on the Mariah inventory, 14 appear to be eligible for the National Register of Historic Places, 24 are potentially eligible, and two are not eligible. (A determination of eligibility can be made only after the site has been archaeologically tested.) None of the 75 isolates are considered eligible. While the date from the various researchers cited above are not always consistent with Mariah's explicit data on site significance, it appears that within the withdrawal ares the majority of sites either are or have the potential to be ellgible for the National Register of Historic Places and will require consideration in future land disturbing activities.

\subsection{Affected Orazing Environment}

The Act requires that grazing management be conducted in accordance with applicable grazing laws and policies, including: the Act entitled "An Act to stop injury to public grazing lands by preventing overgrazing and soil deterioration, to provide for their orderly use, improvement, and development, to stabilize the livestock industry dependent upon the public range, and for other purposes, " approved June 28, 1934 (43 U.S.C. 315 et seq., commonly referred to as the "Taylor Grazing Act"); title IV of the Federal Land Policy and Management Act of 1976 (43 U.S.C. 1751 et seq.); and the Public Rangelands Improvement Act of 1978 (43 U.S.C. 1901 et seq., and 43 CFR Part 4100).

The principles of multiple-use and sustained-yield are basic to the management of this program. Rangelands comprise a substantial portion of the withdrawal area and provide forage for domestic livestock and valuable wildilfe habitats.

The WIPP withdrawal area affects two grazing allotments administered by the BLM: the Livingston Ridge (77027) and the Antelope Ridge (77032) (Figure 2.1). 


\section{GRAZING ALLOTMENT BOUNDARIES WITHIN THE WITHDRAWAL AREA}

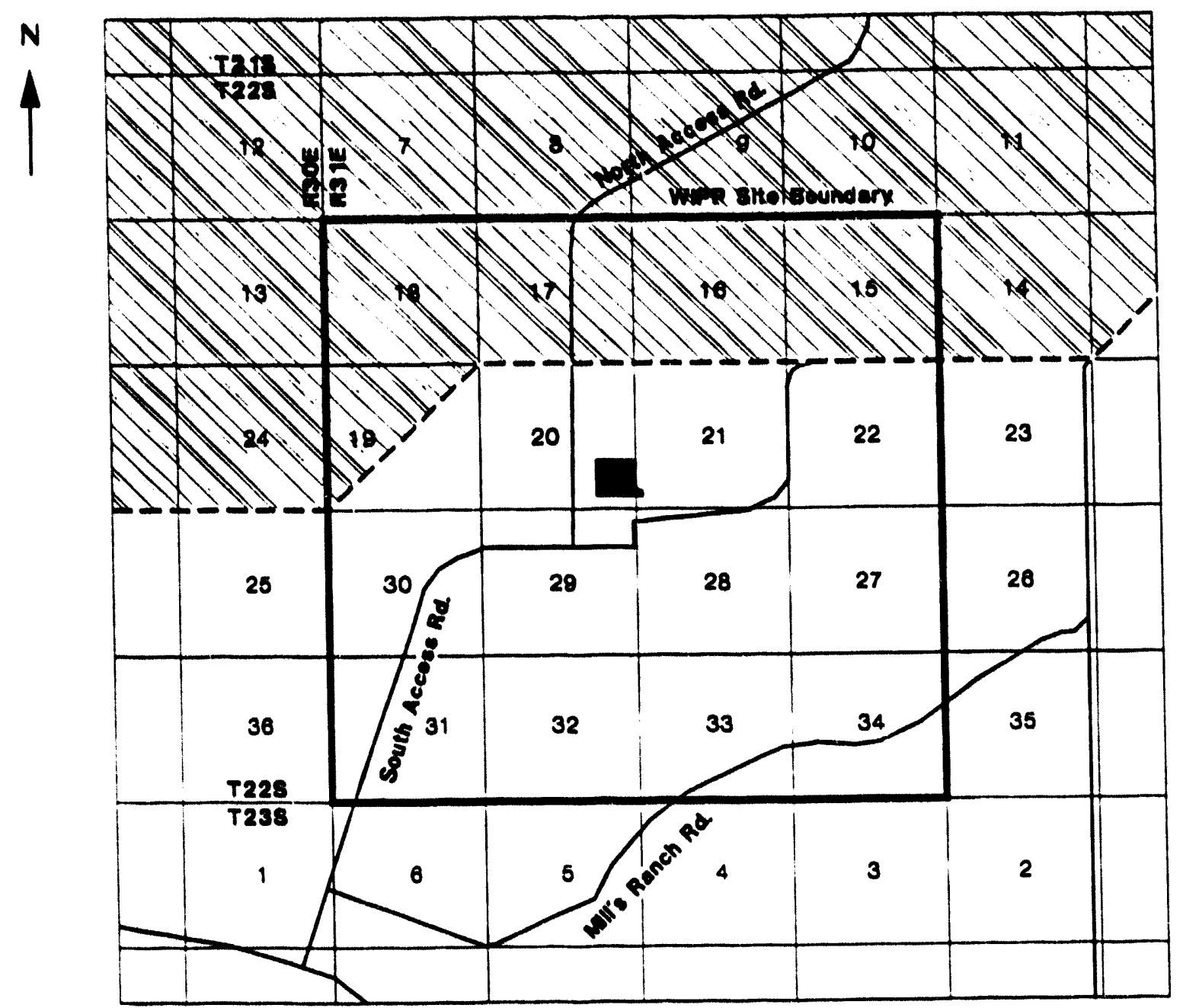

\footnotetext{
Livingston Ridge Allotmont

$\square$ Antelope Ridge Allotmont

- - Allotment Boundary
}

Figure 2.1 
The Livingston Ridge allotment begins 17 miles east of Carlsbad, New Mexico. The allotment is 55,581 acres in size and permitted to a livestock rancher operating a year-round cow/calf business. Land ownership is divided between Federal, State, and private lands. Acreages distributed by ownership are as follows: (1) 41,608 acres of Federal ownership (2,880 acres within the withdrawal area), (2) 13,063 acres owned by the State, and (3) 910 acres of private land. Although the allotment is 55,581 acres in size, only 5.18 percent of the allotment is within the WIPP site.

Pasture rotation, with some of the pastures being rested for at least a portion of the growing season, is standard management practice for this allotment. Vegetative monitoring studies to collect data on the utilization of the land, and the amount of precipitation by pasture from each study allotment are conducted annually to compare production with consumption. Should vegetative monitoring studies indicate a need for an allotment management plan, a plan will be developed in consultation with the BLM. The allotment is permitted for 6,483 Animal Unit Months (AUMs), which converts to 6.3 acres/AUM. (An AUM is the anount of forage necessary for the sustenance of a cow, or its equivalent, for a period of one month.)

The Antelope Ridge allotment begins 23 miles east of Carlsbad, New Mexico, and contains 77,574 acres. The allotment is permitted to a livestock rancher operating a year-around cow/calf business. Approximately 300 acres within the Antelope Ridge allotment contain the WIPP facilities and are posted against trespass and fenced to prevent grazing. Land ownership is divided between Federal, State, and private lands. Acreages distributed by ownership are as follows: (1) 66,757 acres of Federal land (7,360 acres within the withdrawal area), (2) 8,749 acres owned by the State, and (3) 2,068 acres of private land. This allotment of 77,574 acres has only 9.49 percent of the allotment within the WIPP site.

An allotment management plan has been developed for this allotment by the BLM. The plan includes a seven-pasture rotation system, with some pastures being rested for full years and others receiving growing season rest. The allotment is permitted for 13,236 AUMs, which converts to 7.0 acres/AUM. 
Both allotments consist of sandy and deep sand range sites. These range sites have a grassland aspect and include grasses such as gramas (Bouteloua spp.), Bluestems (Andropogon spp.), and Dropseeds (Sporobolus spp.). Other key plant species include: mesquite, Havard shinnery oak, Crotons, and Globemallow.

\subsection{Recreation within the Affected Environment}

Due to the topography, climatic conditions, and wildlife in the area, recreational activities in the vicinity of the WIPP site are restricted primarily to hunting and trapping with occasional use by off-road vehicles (ORVs) and recreational horseback riders.

Hunting and trapping privileges for the public within the withdrawal area will continue, except the DOE, after consultation with the BLM and the State of New Mex .o, may issue regulations designating zones where, and establish periods when, no hunting or trapping is permitted for reasons of public safety, administration, or public use and enjoyment. No decision to issue regulations has been made at the time of release of this land management plan.

\subsection{Access inte the Affected Environment}

The WIPP site can be reached by rail, highway, or primitive road (usually associated with a pipeline right-of-way). The DOE has constructed a rail spur to the site from the Atchison, Topeka and Santa Fe Railroad six miles west of the site, with a corresponding easement road, which parallels the spur on the south side. The site can be reached from the north and south access roads constructed for the WIPP Project. The north access road intersects U.S. Highway 62/180 13 miles north of the site. The south access road intersects New Mexico Highway 128 four miles to the southwest. 


\subsection{Emergency/Security within the Affected Environment}

The WIPP site maintains 24-hour readiness in the event of any emergency. The WIPP will respond to emergencies with fire fighting capabilities and emergency medical technicians in accordance with the Mutual Aid Agreements in place with Carlsbad, Hobbs and Eddy County, New Mexico.

Security for the WIPP site consists of a staff of security officers, with support personnel. A minimum of three officers are on duty at any given time, with shift rotations occurring every twelve hours. The WIPP security force maintains field vehicles, which are used several times daily for perimeter inspections. The WIPP security force has the authority to perform protective duties under the Atomic Energy Act of 1954.

\subsection{Affected Socioeconomic Environment}

The socioeconomic environment of the area consists primarily of ranching, oil and gas extraction, and mining (specifically potash).

There are 26 permanent residents at various locations within ten miles of the WIPP site. Most of the population within 50 miles of the WIPP site is concentrated in and around the communities of Carlsbad, Hobbs, Eunice, Loving, Jal, and Artesia, New Mexico. The nearest community is the village of Loving, New Mexico, 18 miles west-southwest of the WIPP site. The population of Loving decreased from an estimated 1,600 in 1980 to 1,243 in 1990, the year of the latest census. The nearest major population center is the city of Carlsbad, New Mexico, 26 miles west of the WIPP site. The population of Carisbad has increased from an estimated 28,600 in 1980 to an estimated 29,500 in 1990 . The transient population within ten miles of the WIPP site is associated with ranching, maintenance of oil and gas wells, and potash mining.

There are three ranches within five miles of the WIPP site: the Mills, Smith, and Mobley ranches. Only the Mills ranch has a permanent residence located within five miles of the 
WIPP site. Three mining operations within ten miles of the WIPP site employ approximately 360 persons per shift, with 450 persons present during shift changes.

\subsection{Water Service Pipeline within the Affected Environment}

Water service for the WIPP facility is furnished by a water line that originates 31 miles north of the facility. The maintenance and operation of the water line is accommodated through a cooperative agreement (Contract DE-AC04-85AL24138-M002) between the DOE and the city of Carlsbad. The volume capacity of the water line is such that it meets all water requirements for the operation of the WIPP facility, as well as provides the city of Carlsbad with untreated water.

\subsection{Groundwater Surveillance within the Affected Environment}

The DOE monitors 58 well bores and their corresponding locations on or in the vicinity of the WIPP site. These well bores are used to conduct surveillance of groundwater levels. In addition, eight of the $\mathbf{5 8}$ wells contribute data to the Water Quality Sampling Program of the WIPP. Well locations are periodically inspected, the existing well pads examined, and any nonconformities identified and addressed. In the event that a well is considered inoperative, the well and its corresponding well pad will be decommissioned and reclaimed accordingly.

\subsection{Salt Tailings within the Affected Environment}

Salt, which is extracted from underground mining operations at the WIPP, is stored just north of the facility. This bermed salt pile currently comprises 407,666 cubic yards of excavated salt for future maintenance, alcove excavation, etc., and may increase in the future depending on underground activities. Additionally, there is a second pile, comprised of 162,103 cubic yards, called the Site and Preliminary Design Validation (SPDV) pile. This pile is a result of drilling one 12-foot diameter and one 6-foot diameter

shaft to the repository depth of 2,150 feet. Added to the SPDV pile was the material from the excavation of the connecting and exploratory tunnels and four rooms excavated 
to the repository disposal room design dimensions. This activity was in support of the SPDV program. The DOE intends to relocate this material to the bermed salt pile for containment purposes.

Since 1985, ecological studies have been conducted to determine the impacts of surface storage of salt on the surrounding environment. Investigations, ranging from microbial studies to the evaluation of plant and animal communities, determined that there has been no migration of the salt into the peripheral environment. As salt is brought up from the underground, its moisture content is extremely low and thus it exhibits hydroscopic properties. Accordingly this salt absorbs moisture, crystallizes and is joined to other small salt crystals to form a very large rock salt structure. This recrystallization binds the salt so that there is no migration of salt to the adjoining environments, however, small amounts of salt dust may be disbursed during salt unloading activities. DOE has concluded that the exposed salt has minimal environmental impact and is not considered an environmental hazard. A summary of the Salt Impact Studies at the WIPP, 1984-1990 (DOEMIPP 92-038), elaborates on salt storage at the WIPP site.

\subsection{Air Quality in the Affected Environment}

Air quality impacts associated with the construction and operation of the WIPP facility were assessed in the National Environmental Policy Act (NEPA) Documentation including the FEIS issued in October 1980. They were considered again in the Supplemental Environmental Impact Assessment in 1989. In both instances, the only airborne effluents were identified to be "salt dust from mining and the surface salthandling system, small gas releases from experiments with waste, gases and particulate emitted by fuel-burning equipment and motor vehicles, and dust from erosion by wind" (DOE, 1980). The effects of emissions on local air quality were evaluated using sitederived meteorological data and standard air dispersion models. DOE concluded that the projected quantities of emissions would produce "no significant environmental effects." The permanent withdrawal of the WIPP lands and the authorization in the Act to operate the WIPP facility has not changed the impacts or the assessment found in the applicable NEPA documentation. 
The DOE has taken measures to monitor the impacts to air quality and has installed systems to mitigate adverse impacts that may be associated with unexpected events. These systems and activities are described in numerous project documents including the Final Safety Analysis Report and include high efficiency particulate air filtration systems, fuel selection, and effluent monitoring systems. In addition, the DOE has prepared documentation in compliance with the requirements of the National Emission Standards for Hazardous Air Pollutants for radionuclides under the Clean Air Act and is seeking an air quality permit for two diesel powered emergency power generators. The DOE has no plans that would increase the types of emissions projected for the facility.

\subsection{Sewage Lagoon System within the Affected Environment}

The WIPP sewage lagoon system is a zero-discharge treatment facility consisting of two primary settling lagoons, two polishing lagoons, a chlorination system, and three evaporation basins. The entire facility is lined with $\mathbf{3 0}$ mil synthetic liners. The facility is designed to dispose of domestic sewage and site-generated brine waters from observation well pumping and from Air Intake Shaft dewatering activities at the site.

The WIPP sewage facility is operated under the New Mexico Discharge Plan (DP831) and managed in accordance with the EPA sewage sludge regulations (40 CFR 503), the New Mexico Solid Waste Management Regulations (Part 700), the New Mexico Water Quality Control Regulations (3-100), and the WIPP Sewage Sampling Procedure, WP 02-505. These requirements provide guidance for disposal of domestic sewage, sitegenerated brine waters, and site-generated non hazardous waste waters.

A determination is made on a case-by-case basis to determine regulatory requirements for on-site or off-site disposal of sewage sludge. Small quantities of sludges generated at the WIPP site have been used as fertilizer and soil stabilizers for the WIPP reclamation projects. All sludges are analyzed in accordance with regulatory requirements of 40 CFR 503 before they are applied to the reclamation areas. 


\subsection{Beclamation of the Affected Environment}

In accordance with commitments made in the FSEIS and the FEIS, the WIPP has implemented a contemporary reclamation program and corresponding long-range plan. As locations are identified for reclamation, WIPP personnel will reclaim these areas by using the best acceptable reclamation practices. Seed mixes used will reflect those species indigenous to the vicinity and priority will be given to those plant species which are conducive to soil stabilization, livestock, and wildlife needs.

\subsection{Critical Elements of the Environment}

The following elements of the environment, as identified in the NEPA Handbook, are subject to requirements specified in statute, regulation, or executive order and have been considered and DOE has determined that they are not affected by WIPP activities or by land management actions within the withdrawal:

Areas of Critical Environmental Concern

Federal Land Policy and Management Act of 1976 (43 USC 1701 et. seq.)

Prime or Unique Farmlands

Surface Mining Control and Reclamation Act of 1977 (16 USC 470)

Floodplains

E.O. 11988, as amended, Floodplain Management, 5/24/77

Native American Religious Concerns

American Indian Religious Freedom Act of 1978 (42 USC 1996)

Wetland/Riparian Zones

E.O. 11990, Protections of Wetlands, 5/24/77

Wild and Scenic River

Wild and Scenic Rivers Act as amended (16 USC 1271)

Wilderness

Federal Land Policy and Management Act of 1976 (43 USC 1701 et. seq.) Wilderness Act of 1964 (16 USC 1131 et. seq.) 


\section{CHAPTER 3}

\subsection{MANACEMENT OB.JECTIVES AND PLANNED ACTIONS}

This section describes the DOE's land management objectives and planned actions to accomplish these objectives.

\subsection{Willdife}

\subsubsection{Objective}

DOE's objective is to maintain the ecological condition of wildlife habitat within the WIPP withdrawal area.

\subsubsection{Planned Actions}

Wildife habitat management objectives place special emphasis on the protection and maintenance of (1) crucial habitats for big game, upland game birds and waterfowl, (2) crucial habitats for nongame species of special interest and concern to State or Federal agencies, and (3) habitat for State or Federally listed threatened or endangered species identified as inhabiting the withdrawal area.

Wildlife forage and cover requirements will be considered in any management action that is proposed for the withdrawn lands. Should range improvement projects be developed (e.i'., installation of livestock watering units), they will be designed to accommodate wildlife needs. With any proposed habitat improvement projects, a determination will be made regarding the applicability of NEPA documentation. 


\subsubsection{Soncial Stanun songine}

\subsubsection{Obinative}

DOE's objective is to protect the habitat for populations of special status species within the withdrawal area. Any management action that would affect the habltat or existence of a threatened or endangered species will comply with the Threatened and Endangered Species Act of 1973, as amended.

\subsubsection{Planned Aations}

Activities will not be permitted in habitats of threatened, endangered, or sensitive species that would jeopardize their continued existence. The New Mexico Forestry and Resources Conservation Division-Resource Survey Section, the NMDGF, the USFWS, and the BLM will be consulted prior to implementing proposed projects that may affect threatened or endangered species habitat. If a preliminary determination is made during the assessment process that the proposed project could affect threatened or endangered species habitat, then consultation with the USFWS will be Initiated under section 7 of the Endangered Species Act of 1973, as amended.

In the event a special status species is found occupying the withdrawal area, necessary procedures will be employed to ensure its success and survival, and priority will be given to development of a recovery plan for that threatened or endangered species.

\subsubsection{Wild dife Hablitas}

\subsubsection{Objective}

DOE's objective is to maintain habitat within the withdrawal area for ungulates, raptors, and upland game. 


\subsubsection{Pinnned Aations}

\section{Ungulates}

1. All new llvestock water development within the withdrawal area will be made eccessible to wild ungulates.

2. Reclamation efforts will employ the use of plant species for wildlife (fourwing saltbush, Apache plume, perennial sunflower, etc.).

3. Should brush control methods be initiated, the needs of wildilfe will be considered.

\section{Raptors}

1. The BLM and the WIPP Project Site Office (WPSO) will continue the Raptor Research and Management Program, Interagency Agreement No. 1422G910-A20016. This program will increase the level of understanding of raptors and provide for better raptor management by the BLM and the WIPP. By involving both agencies, the raptor study area will be expanded, thus allowing additional data to be collected regarding the raptor populations of the area.

2. Power lines within the withdrawal area will be constructed in a manner to prevent the electrocution of raptors, a standard stipulation that is attached to the BLM's power line construction permits.

\section{Upland Game}

1. Habitat needs for the Lesser Prairie Chicken within the withdrawal area will be considered with any surface disturbing activities. 
2. Reclamation efforts will use vegetative and plent species that will enhance cover and provide a food base for upland game birds.

3. All new llvestock water development within the withdrawal aree will be equipped with bird ramps.

\subsection{Gultural Bonouren}

The purpose of the cultural resource program is to inventory, evaluate, and manage cultural resources within the withdrawal area. The BLM's Carlsbad Resource Menagement Plan (RMP) is used as guldance for management of the cultural resources.

\subsubsection{Obinativen}

DOE's objectives are to:

1. protect and preserve representative samples of the full array of cultural resources for the benefit of scientific and socio-cultural use by present and future generations;

2. ensure that cultural resources are given full consideration in land use planning and management decisions; and

3. manage cultural resources so that scientific and socio-cultural values are not diminished.

\subsubsection{Planned Actione}

1. DOE will continue to inventory and evaluate cultural resources. Any proposed undertaking in an area that has not had a cultural resource inventory performed will have one completed, with potential impacts being addressed in a document that meets the requirements of the NEPA. Recommendations generated from the 
evaluations will consider the impacts of the proposed projects to cultural resources in affected areas.

2. The identification, evaluation, and treatment of cultural resources will be conducted under section 106 of the National Hlatoric Preservation Act of 1986, as amended and 36 CFR 800, prior to proceeding with the proposed undertaking. As cultural resources are identified, they will be evaluated in consultation with the Now Mexico State Historic Preservation Officer (SHPO) and the BLM to dotermine thair ellglbility for listing on the National Register of Historic Places. The evaluation will follow the criteria presented in 36 CFR Part 60.4.

3. Sites which are found to be eligible for listing in the National Register of Historic Places will be avoided to the maximum extent possible. Where avoidance is not possible, mitigative measures designed to treat the effects of the undertaking will be developed and implemented in consultation with the SHPO and the BLM.

\subsection{Grezing Mannanment.}

\subsubsection{Oblactive}

DOE's objectives for grazing management are based on the current practices for adjacent public lands .- maintaining rangeland resource values on a long term, sustainedyield basis. Vegetative monitoring studies of key forage species are the mechanism by which the need for range management changes would be detected.

The withdrawal area is a complex ecosystem composed of plant and animal communities and basic soil types, all responsive in one way or another to natural processes such as rain, wind, sunlight, and man's activities. No single element in the range ecosystem is 80 readily managed and with such far-reaching effects as is vegetation. Consequently, maintaining the vegetation component of this ecosystem is necessary to achieve a balanced mix of uses. 
Tho WIPP withdrawal aree affects two grazing allotments administered by the BLM: the Livingston Ridge (77027) and the Antelope Ridge (77032). Portions of both allotments lie within the withdrawal area. An ares of 300 acres within the Antelope Ridge allotment contains the WIPP facilities and is posted against trespass and fenced to prevent grazing. This is the only area within the withdrawal aree that is not currently used for livestock activity. The DOE's intent is to continue current management practices, unless a need develops to modify those practices. Grazing will continue, uninterrupted, on the withdrawn lands as it has since the inception of the WIPP Project.

\subsubsection{BinnnedAations}

The following planned actions will be administered by the BLM, for the DOE, in consultation with the State of New Mexico and affected county, State, and Federal agencies.

1. Continue vegetative monitoring program in the withdrawal area to determine If the goals and objectives of the grazing allotments are being achieved As - minimum, the monitoring program will include collecting date on actual livestock use, wildilfe use, degree of utilization of the key forage species, climatic conditions, and rangeland ecological condition and trend. When changes occur in resource values, recommend, where appropriate, courses of action to address those changes.

2. Continue to manage the two grazing allotments under principles of multipleuse management and sustained yield.

3. Should new or replacement livestock watering units be required, the water for the units may be supplied from the Double Eagle Water System. Should the watering units be connected to the Double Eagle Water System, the DOE will require the allottee to meet the requirements identified in the water line contract with the City of Carlsbad (DE-AC04-85AL24138-M002). This will ensure the overall system design adheres to the New Mexico 
Environmental Department's water system supply regulations. No livestock water well drilling will be allowed within the withdrawal area.

4. Continue the range management program in the withdrawal area in accordance with the Taylor Grazing Act, FLPMA, and the Public Range Improvement Act of 1978 which relate to issuance of permits, bills, transfers, and day to day grazing operations.

\subsection{Bearention}

\subsubsection{Obleative}

DOE's objectives are to maintain recreation resource values on a long-term, sustained-vield basis and to continue to provide opportunities for individuals to participate in recreational activities within designated areas of the withdrawal area.

\subsubsection{Planned Aations}

Within Sections 20, 21, 28, and 29 of T. 22 S., R. 31 E., of the WIPP site, the DOE intends to designate an ares of 1,454 acres as an Off-Limits Area. This 1,454 acre area will be posted against trespass under the authority of $\$ 229$ of the Atomic Energy ACt, 42 U.S.C. 2278a, and pursuant to the regulations set forth in 10 CFR 860 and DOE Order 5632.6, "Physical Protection of DOE Property and Unclassified Facilities." DOE has decided to take this action to protect the security and safety of the WIPP site personnel and premises. 


\subsubsection{Qurdoor Begreation Management}

\subsubsection{Oblective}

DOE's objective is that the withdrawal area should afford dispersed recreation and that visitors should have a freedom of choice with minimal regulatory constraint.

\subsubsection{PlennedAations}

Because significant public recreation opportunities and management concerns are limited, DOE has decided not to develop detailed plans for the use of the ares outside the boundary of the proposed 1,454 acre "Off-Limits Area". That part of the withdrawal area that will be open to the public will be monitored to avoid degradation of the environment in conjunction with the DOE's environmental monitoring programs.

\subsubsection{Hunting and Trapoing}

\subsubsection{Objectives}

When the 1,454 acre "Off-Limits Area" is posted against trespass, it is the intention of the DOE to allow hunting and trapping outside this boundary in accordance with applicable Federal and State laws and regulations.

\subsubsection{Planned Actions}

The DOE, after consultation with the BLM and the State of New Mexico, may issue regulations designating zones where, and establish periods when, no hunting or trapping is permitted for reasons of public safety, administration, or public use and enjoyment. DOE has no intent at the time of issuing this plan to develop such regulations. 


\subsubsection{Off-Road Vehicle Designations}

\subsubsection{Objectives}

DOE's objective is to designate Off-Road Vehicle (ORV) limitations within the withdrawal area to protect soils, vegetation, wildlife, and other natural and cultural values, which may be adversely affected by motorized vehicles.

\subsubsection{Planned Actions}

The withdrawal area is designated a "Limited Area." This means that recreational motor vehicle use can be restricted at certain times, in certain areas, and/or for certain specified purposes to protect the health and safety of the public or for common defense and security of the site. These restrictions generally relate to the following:

(a) Numbers of vehicles

(b) Types of vehicles

(c) Time or season of use

(d) Permitted or licensed use only

(e) Use on existing roads and trails

(f) Use on designated roads and trails

(g) Other restrictions as necessary

The withdrawal area will be posted at access points limiting ORV use to existing roads and trails. Other actions to support vehicle management within the withdrawal area could include on-site posting of directional, informational, or other signs to clearly communicate operating rules to vehicle users; and deveioping news releases, brochures, or other informational and educational materials for the public. 


\subsubsection{Visual Resources Management}

\subsubsection{Objectives}

DOE's objectives for the Visual Resources Management program are based on natural scenic quality; visual sensitivity, or the degree of concern expressed by the public for the scenic values; and distance zones (foreground, middleground, or background views) from major travel routes and viewpoints. DOE's objectives will be to maintain scenic quality, consistent with DOE program responsibilities at WIPP, and to consult with the public and governmental entities on how best to achieve this.

\subsubsection{Planned Actions}

The DOE will implement the BLM's Visual Contrast Rating System to determine the degree to which any proposed projects or other activities within the withdrawal area would affect the visual quality of the landscape. Using this system, any anticipated unacceptable visual impacts can be mitigated during the planning and design stage.

\subsection{Mining and Oil and Gas Production}

\subsubsection{Objective}

DOE's objective with respect to mining and oil and gas production is to ensure that the development of on-site and off-site mineral leases do not affect the integrity of the repository.

The resources that are known to underlie the withdrawal area are caliche, gypsum, salt, sylvite, langbeinite, crude oil, natural gas, and distillate. Potassium salts (sylvite and langbeinite), which occur in strata above the repository, and hydrocarbons (crude oil, natural gas, and distillate), which occur in strata below the repository, are the only resources of practical significance and may be considered reserves. ("Resources" are minerals that are currently or potentially of economic value; "reserves" are the portion 
of the resources that can be recovered economically at today's market prices and with existing technology.)

In accordance with section 4(b)(5) of the WIPP Land Withdrawal Act, no surface or subsurface mining unrelated to the WIPP Project or oil or gas production, including slant drilling from outside the boundaries of the withdrawal area, are permitted at any time (including after decommissioning) on lands on or under the withdrawal area with two exceptions. These exceptions are two 320-acre tracts of land within the withdrawal area that are leased for oil and gas development below 6000 feet (Federal Oil and Gas Leases No. NMNM 02953 and No. NMNM 02953C). Both tracts, located in T. 22 S., R. 31 E., Section 31, prohibit drilling within the first 6,000 feet of the surface (Figure 3.1). In accordance with the Act, existing rights under these leases will not be affected unless the Administrator of the Environmental Protection Agency determines, after consultation with the Secretary of Energy and the Secretary of the Interior, that the acquisition of such leases by the Secretary of Energy is required to comply with the disposal regulations or with the Solid Waste Disposal Act, as set forth in section $4(b)(5)(B)$.

\subsubsection{Planned Actions}

Drilling and mining activity within one mile of the withdrawal boundary will be monitored by the DOE in coordination and cooperation with the BLM and/or the State of New Mexico. The BLM and the appropriate State agencies have agreed to forward Applications for Permit to Drill and mining and reclamation plans to the DOE for review and comment in determining issuance of any drilling or mining permit within one mile of the withdrawal boundary. This review will afford the DOE the opportunity to verify that proposed oil and gas or mining activities surrounding the withdrawal area will not encroach upon the withdrawn lands. 


\section{OIL AND GAS LEASES IN SECTION 31 OF THE WIPP LAND WITHDRAWAL AREA}

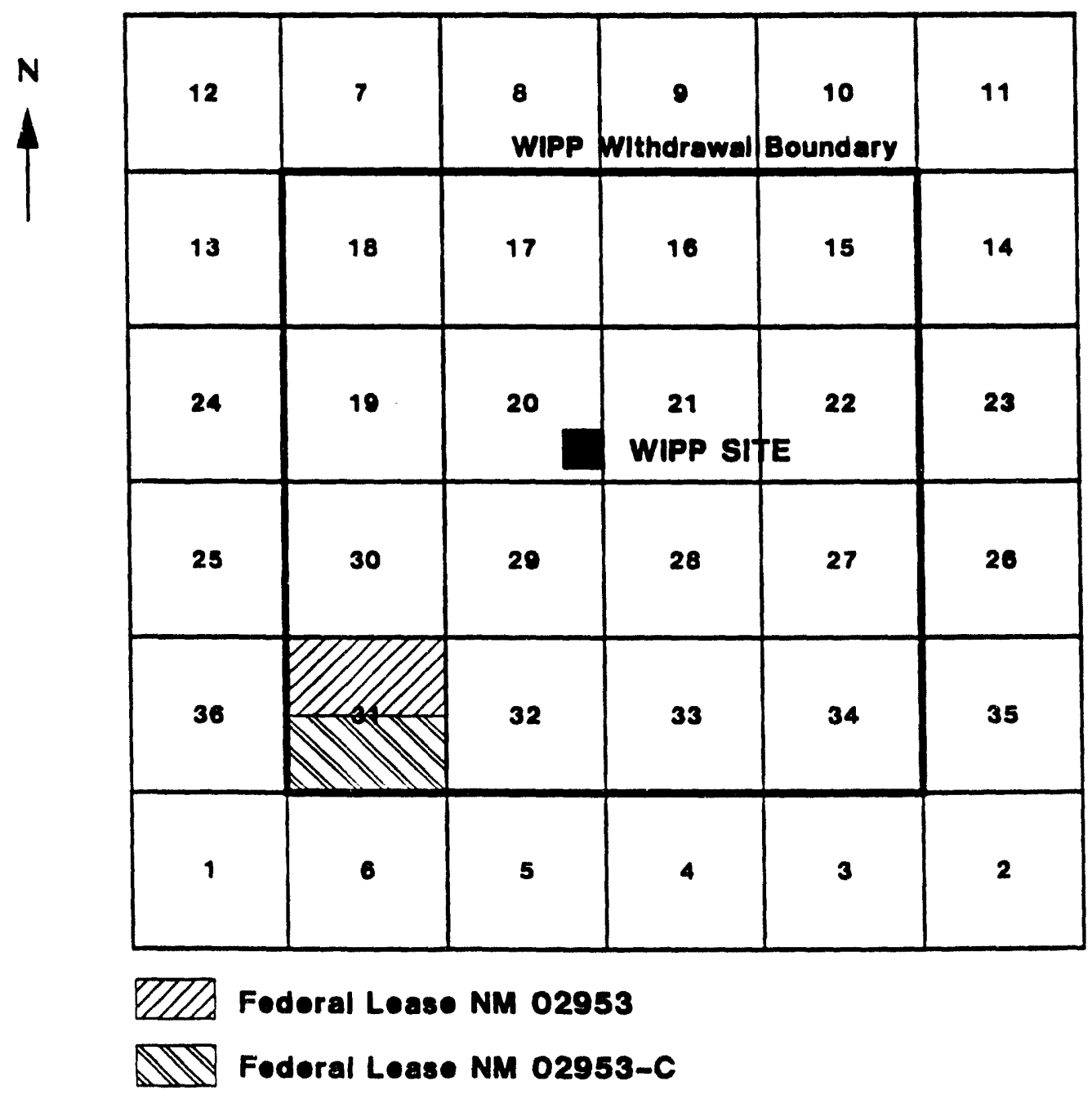

Figure 3.1 
In instances where operators seek permits to drill or mine at a location in close proximity to the withdrawal boundary, the DOE will request through formal agreements with the BLM and/or the appropriate State agencies that they will include as a permit condition that the operator provide the DOE with drill site downhole vertical deviation surveys contemporaneous with the drilling activity. Ongoing review of these surveys by the DOE will serve to detect any potential for subsurface encroachment. Should a downhole vertical deviation survey indicate a potential for subsurface encroachment, the BLM may require the operator to take corrective measures, (i.e. side tracking) or cease drilling activity. Other permit activities related to oil and gas production and mining within this area will be reviewed by the DOE, the BLM and/or the appropriate State agencies on a case-by-case basis.

The transmittal of proposed resource extraction applications or mining plans to the DOE by the BLM and/or the appropriate State agencies will be formalized through MOUs. The MOUs will detail specific responsibilities of the parties involved and protocols to be followed.

\subsection{Rights-of-Way}

\subsubsection{Objective}

DOE's objective is to ensure proper management and maintenance of DOE rightsof-ways affecting the withdrawal area.

The major rights-of-ways for the operation of the WIPP facility have been acquired from the BLM. The DOE shall consult with the BLM and the State of New Mexico, as appropriate, on future right-of-way actions needed outside the withdrawal area. These future actions will comply with applicable regulations at the time of DOE's request. The existing rights-of-way traversing the withdrawal area are shown in Figure $\mathbf{3 . 2}$ and listed below. 
Lenath (miles)

Blaht-of-way

North access road

South access road

Access railroad

Natural gas pipeline

Electricity

Water line (extension)

Telephone
Total Off-site*

13

43

62

204

1410

$16 \quad 15$

... ...
Width

(feet) Expiration

120

None**

80

N/A

100

None

50

None*.

100

None

None

None

- Outside Withdrawal area

* The right-of-way is granted for perpetuity

*. Contained within the right-of-way of the north access road. 


\section{RIGHTS-OF-WAY FOR THE WIPP}

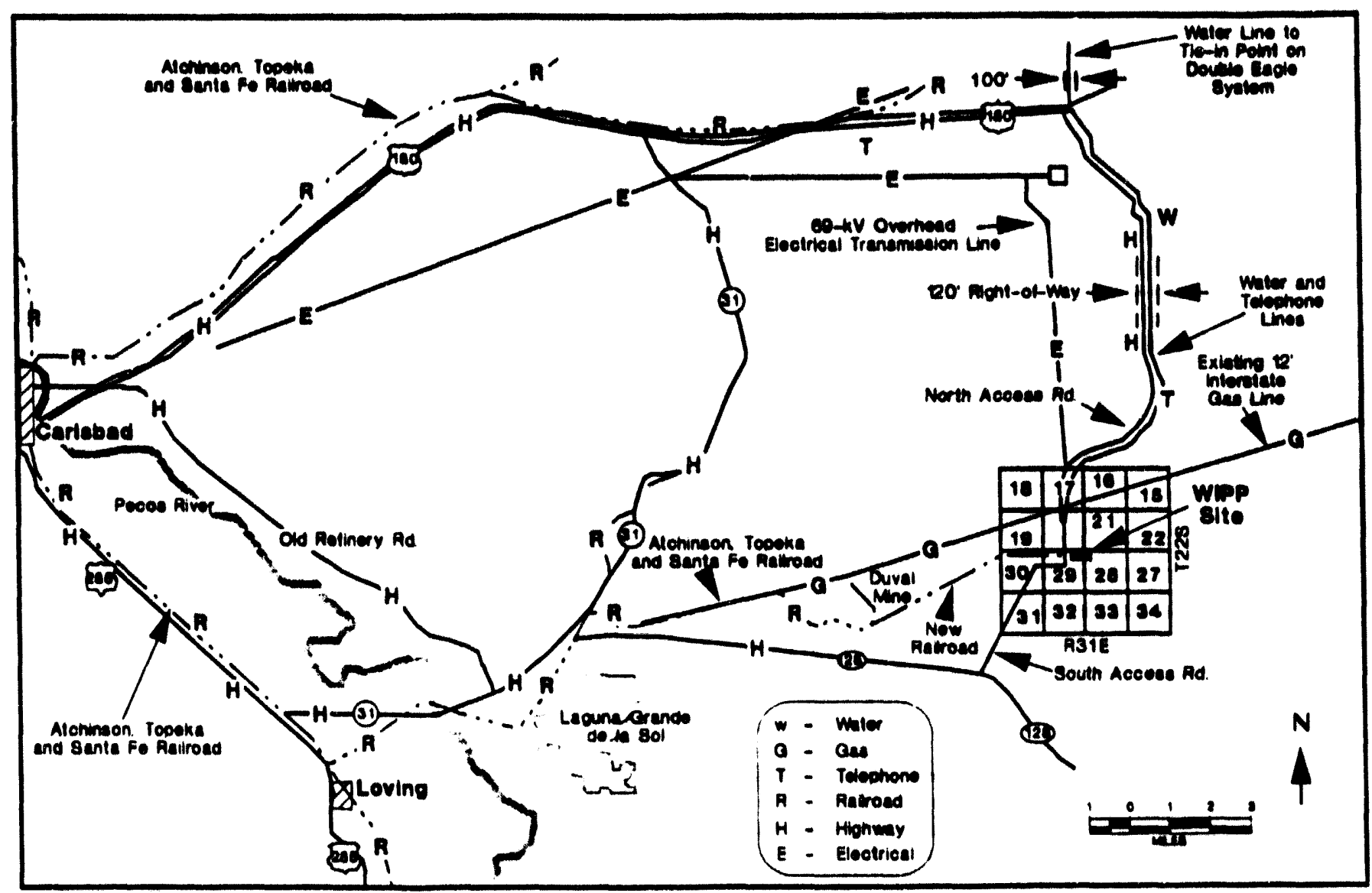

Figure 3.2 


\subsubsection{Planned Aations}

Requests for future rights-of-ways will be administered by the BLM in coordination with the DOE. Details of the administration are covered in the MOU between the DOE and the BLM. The WIPP facility specific rights-of-wey acquisitions are on file at the BLM office in Carlsbad, New Mexico.

\subsection{Accens}

\subsubsection{Obleative}

DOE's objective is to ensure safe and adequate access to the WIPP site while protecting the security of personnel and facilities.

Access to the WIPP site is from U.S. Highway 62/180, 13 miles to the north (North Access Road) and from Highway 128, four miles to the south (South Access Road). Rail access to the WIPP site is provided by a rail line connecting with a spur of the Atchison, Topeka, \& Santa Fe railroad near the Western Ag-Minerals Nash Draw mine six miles southwest of the site (Figure 3.3). Although the Lea County Line Road extension (commonly referred to as the "east access road") leads to the WIPP site, it is a private road and is not regarded as an access road.

The North Access Road and the "east access road" are monitored and maintained by the DOE. The South Access Road is monitored and maintained by Eddy County personnel. Primitive and DOE rights-of-way roads within the withdrawal area are maintained by the DOE while private and/or public rights-of-ways roads are maintained by the applicable parties.

The North Access Road is a private road and shall be restricted for use by the personnel, licensees, permittees, agents, and contractors of the DOE on official business related to the WIPP Project or to personnel, permittees, licensees, 


\section{WIPP SITE ACCESS}

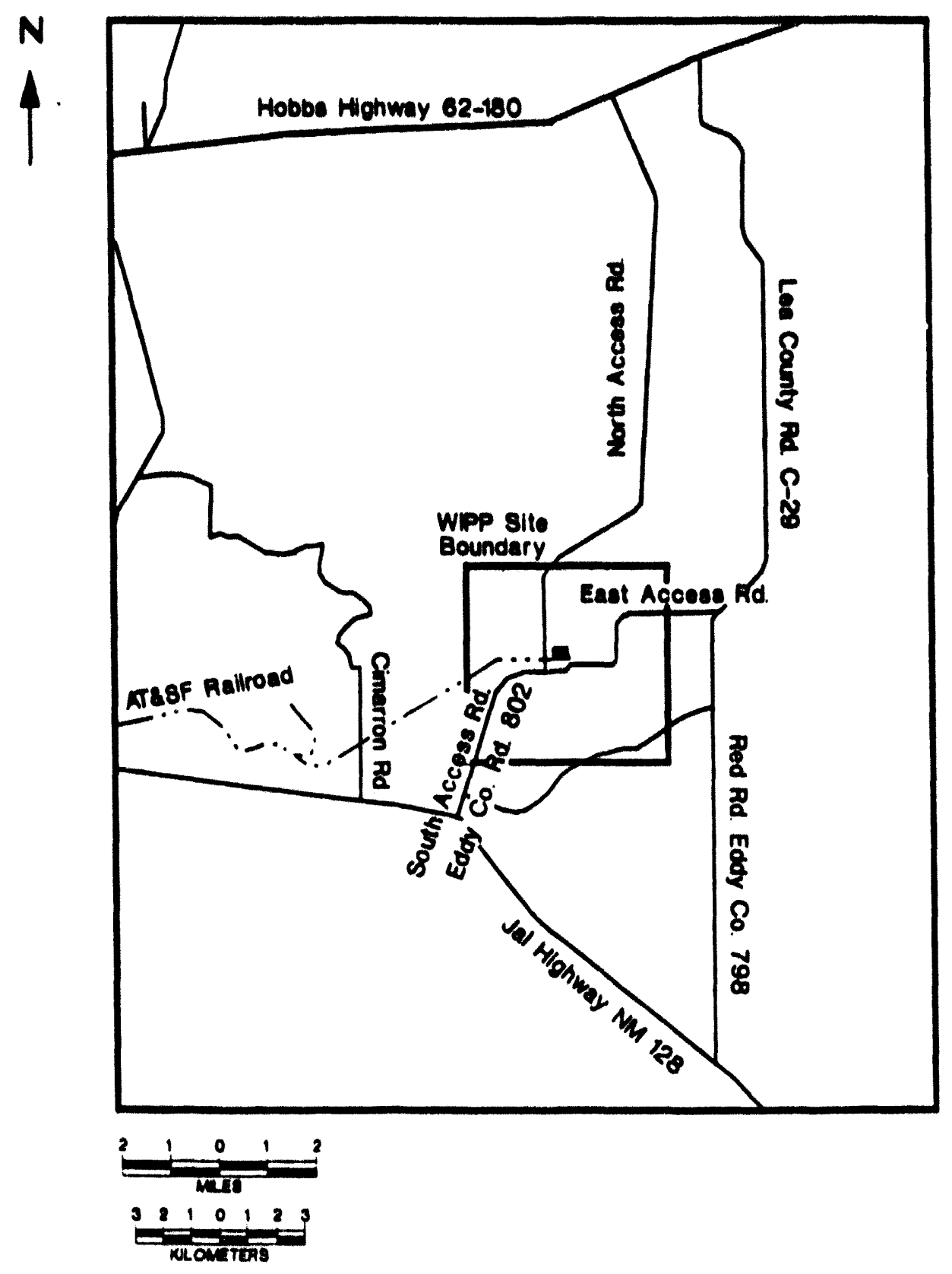

Figure 3.3 
or lessees of the BLM. Signs are placed and will be maintained at the turnout of Highway 62/180 stating the restrictions on access. Persons desiring access to Highway 128 should use the Lea County Line Rosd Immediately to the east.

Eddy County Road 802 is utilized as the South Access Road. This road originates at the turnout of Highwey 128 and terminates as the pevement ends at the confluence of Sections 2829 in T. 22 S., R. 31 E.

The "east access road" is a 4-mile-long paved roadway extending from the Lea County Line Road at the intersection of Sections 13, 14, 22, and 23 of T. 22 S., R. 31 E., to a termination point at the northwest corner of Section 28 of T. 22 S., R. 31 E. The western most 3 miles of this road lies within the WIPP withdrawal area. This roed was built for the purpose of transporting roadbase material for the construction of the North Access Road. Although this road was never intended nor maintained as a thoroughfare, it has experienced an increasing number of private and industrial users. The oil and gas activities in the region constitute the majority of vehicle traffic over this road. By continuing to allow the use of the "east access road, DOE recognizes there exists the possibility of a regulated or hazardous material spill within the withdrawal area.

\subsubsection{Planned Aations}

Under section $4(C)$ of the Act, the DOE is considering whether to close the "east access road" to protect the health and safety of the public. The Act provides that after consultation with the Secretary of the Irterior, the Secretary may take whatever action the Secretary determines necessary to effect and maintain this road closure and provide notice to the public if such closure occurs. The closure to the public of this road that is being considered would be from the confluence of the northeast corner of Section 22 and the northwest corner of Section 23 in T. 22 S., R. 31 E., to approximately 250 yards east of the confluence of Sections 28 \& 29 in T. 22 S., R. 31 E., all within the WIPP site.

An area of 300 acres within Sections 20, 21, 28, and 29 of T. 22 S., R. 31 E., is surrounded by a five-strand barbed wire fence. The fenced area is posted against 
trespass under the authority of $\mathbf{8 2 2 9}$ of the Atomic Energy Act, 42 U.S.C. 2278a, and pursuant to the regulations set forth in 10 CFR 860 and DOE Order 8632.6, "Physical Protection of DOE Property and Unclassified Facillites" (Figure 3.4).

The DOE intends to expanding the posted ares to include 1,464 acres within Sections 20, 21, 28, and 29 of T. 22 S., R. 31 E., in order to ensure the security of the premises and the safoty of persons present at the WIPP feclity. The expanded area would be posted against trespass under the authority of 1229 of the Atomic Eneroy Act, 42 U.S.C. 2278s, and pursuant to the regulations set forth in 10 CFR 860 and DOE Order 5632.6. "Physical Protection of DOE Property and Unclassified Facilities." Although it would be posted, the expanded area would not be fenced.

Signs with the legend "Property of the United States Department of Energy" will be placed around the unfenced perimeter of the 16-section withdrawal area at roadway entrances and other access points. Signs advising against trespassing will be posted at roadway entrances and other access points of the unfenced perimeter of the 1,454 acres within Sections 20, 21, 28, and 29 of T. 22 S., R. 31 E., at intervals deemed appropriate by the DOE.

\subsection{Emargenay and Facllity Segurity}

\subsubsection{Objeative}

DOE's objective of emergency and facility security preparedness is to protect and provide a safe environment for WIPP employees, contractor personnel, visitors, and members of the general public during such potential emergency conditions as serious accidents, external disruptions, or natural disasters. These emergency conditions could be both natural and man-made. The natural conditions of particular concern to the WIPP site include wind, lightning, local floods, earthquakes, tornadoes, and range fires. 


\section{WIPP FACILITY BOUNDARIES}

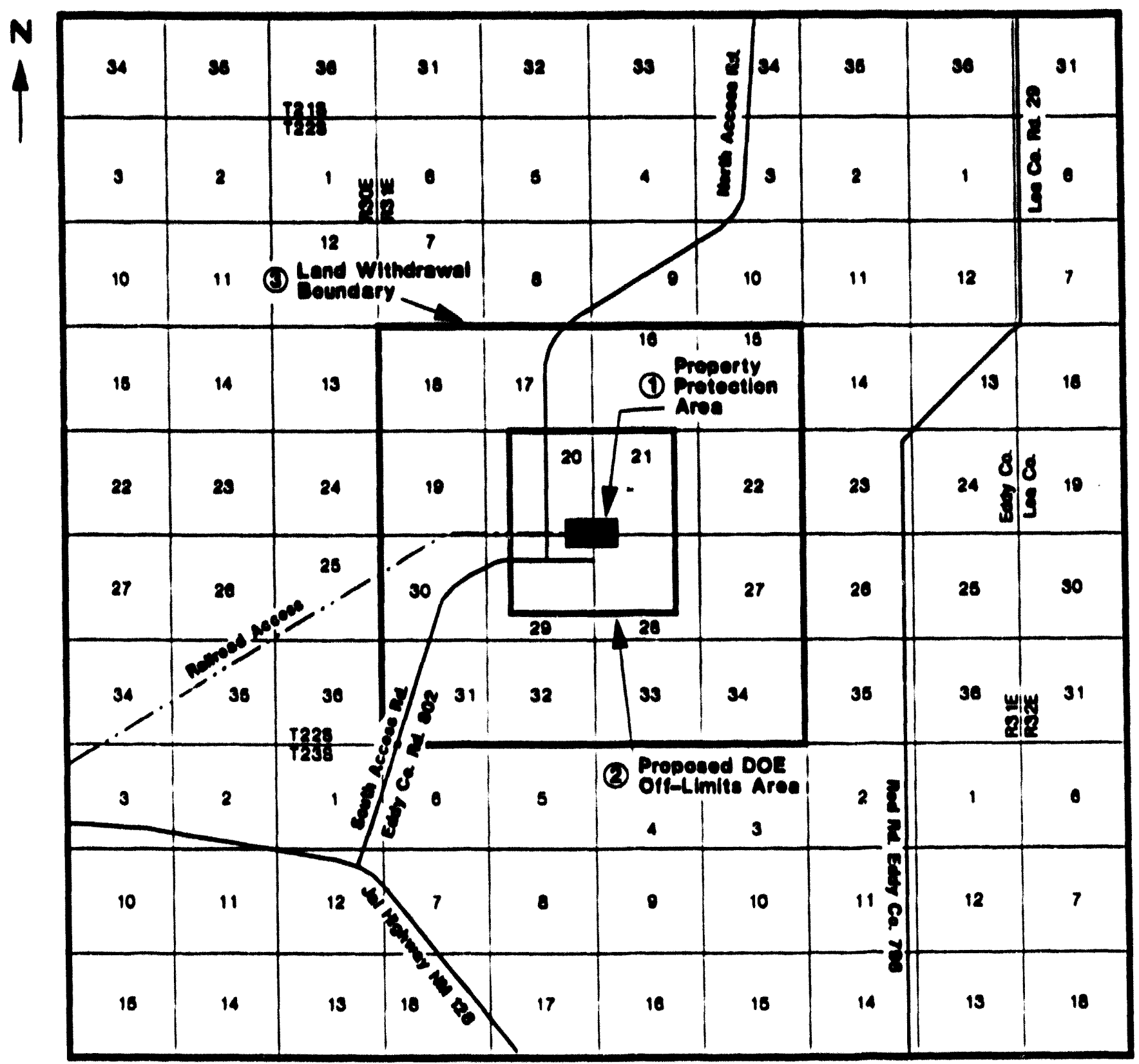

(1) Major WIPp teolltity enelosed by an 8-10ot, ehain Unk tenee and barbod wire outrlegers

(2) Can be posted egainat trespeses

(3) Will be postod by "Information signa" only

Figure 3.4 
Man-made conditions include fires and explosions, loss of power, hazardous atmospheres, external disruptions, mine accidents, hazardous emissions, heat stress, and equipment failure.

The WIPP Emergency Plan, the WIPP Resource Conservation and Reagvery Aat IRCRAL Contingency Plan, and/or the WIPP Security Plan apply to safoty and security omergency preparedness and response actions relative to the following:

- Radiological emergencies

- Underground emergencies (nonradiological)

- Industrial emergencies

- Security emergencies

- National emergencies

- Continuity of government emergencies

- Natural disaster/emergencies

\subsubsection{Planned Aations}

Plans have been implemented to minimize facility or programmatic impacts during an emergency condition at the WIPP site. These plans are the WIPP Emergency Plan, WP 12-9, the WIPP RCRA Contingency Plan, WP 02-12, and the WIPP Security Plan, August 1992, with attendant procedures and documentation.

\subsection{Fire Management}

\subsubsection{Objective}

DOE's objective for the WIPP fire management program is to ensure a timely, wellcoordinated, and cost-effective response to suppress wildfire within the withdrawal area. Wildfire suppression responses are based on several factors, including location of the nearest suppression forces; complexity of the fire; danger to improvements, structures, 
or persons; resource values threatened; availability of additional equipment, and current wildfire conditions.

\subsubsection{Planned Aatione}

Upon detection of a wildfire within the withdrawal area, full suppression strategy is in effect. Under this strategy, the WIPP incident commander must coordinate all activities to ensure wildfires are suppressed and extinguished. Upon detection of a wildfire within the withdrawal area, the BLM's Carlsbad Fire Control Officer shall be notified immediately. WIPP personnel will respond to the wildfire. Upon arrival at the fire, WIPP personnel shall assess the situation and determine if additional support will be required. Should support be required, fire fighters from the BLM as well as Carlsbad, Hobbs, and Eddy County, New Mexico, may be asked to assist in accordance with established Mutual Aid Agreements. The WIPP incident commander shall ensure fire fighting activities adhere to the WIPP Pre-Fire Plans. The WIPP Pre-Fire Plans, kept in the WIPP fire truck and rescue vehicle, identifies entrances, exits, and any potential hazardous materials for each WIPP facility building.

The WIPP fire truck is intended primarily for protection of the WIPP facilities. This equipment must remain avallable for its primary objective. If conditions are such that WIPP personnel choose not to commit their forces to wild fires, the WIPP personnel shall notify the BLM; and the BLM will coordinate suppression efforts.

Water Service Pioeline

\subsubsection{Objeative}

DOE's objective is to manage the water service pipeline to ensure a reliable, safe water supply for the WIPP site, wildlife, and livestock needs.

The water service for the WIPP site is provided by a DOE constructed water line from the city of Carlsbad's Double Eagle Water System to the WIPP site, a distance of 
31 miles. This service is made possible by a water line contract between the DOE and the city of Carlsbad, Contract DE-AC04-85AL24138-M002.

The initial 16-mile segment of the we:s line is a 24 inch diameter line to accommodate the city of Carlsbad deliveries in excess of that required by the WIPP facility. The city of Carlsbad is authorized to use capacity in the initial 16-mile segment that is in excess of $\mathbf{5 0 0}$ gallons per minute, provided that:

- Any such use of the excess capacity by the city of Carlsbad shall be without any cost or liability to the DOE.

- The city of Carlsbad shail notify the DOE not less than $\mathbf{3 0}$ days in advance of the installation of each new tap and/or service capacity commitment which the city of Carlsbad intends to serve from the DOE's line.

- Upon the request of the Contracting Officer (DOE), the city of Carlsbad shall provide a monthly tabulation of deliveries by tap point for the preceding 24 months.

In the final 15-mile (10-inch diameter) segment, the DOE has authorized the $3 / 4^{\text {" }}$ water tap lines to supply water to livestock drinking tanks. Additional tap points may be added from time to time with advance approval of the DOE. Water delivered at such tap points will be metered and billed by the city of Carlsbad consistent with the city of Carlsbad's rates and procedures for providing service to its regular customers.

Future use of the water pipeline within the withdrawai area will be determined at the time of decommissioning of the WIPP facility.

As per Contract DE-AC04-85AL24138-M002, the city of Carlsbad has the duty to provide the DOE's water requirements free of consumption charge and maintain the water line, at its expense, during the initial term of the contract and any optional extension terms thereafter. Single maintenance projects involving repairs or replacements 
that cost in excess of $\$ 10,000$ shall be considered abnormal and shall be funded by the DOE, provided that such repairs or replacements are not the result of the fault or negligence of the city of Carlsbad or its customers, and provided further that the city of Carlsbad shall first obtain the advance approval of the Contracting Officer (DOE) for any maintenance project requiring the DOE funding. This contract shall be renegotiated between the DOE and the city of Carlsbad every five years.

\subsubsection{Planned Actions}

An operating committee, comprised of up to two representatives from the DOE and other affected city, county, State, and Federal agencies, will be formed. The responsibilities of the operating committee shall be:

- To establish standard procedures and practices for the operation and maintenance of the water line.

- To review any technical studies that may be conducted during the term of the contract and keep the DOE Contracting Officer and the city of Carlsbad currently advised as to matters needing attention.

\subsection{Groundwater Surveillance}

\subsubsection{Objective}

DOE's objective for the groundwater surveillance program is to document the effects of operations on ground water quality and quantity and to demonstrate compliance with applicable Federal and State requirements through obtaining representative and repeatable groundwater data from selected wells. DOE Order 5400.1 requires that groundwaters that may potentially be affected by DOE operations 
be examined. There are 58 well bores on or in the vicinity of the WIPP site. Of these 58, 31 active groundwater surveillance well bores are contained within the withdrawal area (Figure 3.5). The depth of these wells ranges from approximately 525 feet to 750 feet. 


\section{GROUNDWATER SURVEILLANCE WELLBORES Within the Land Withdrawal Area}

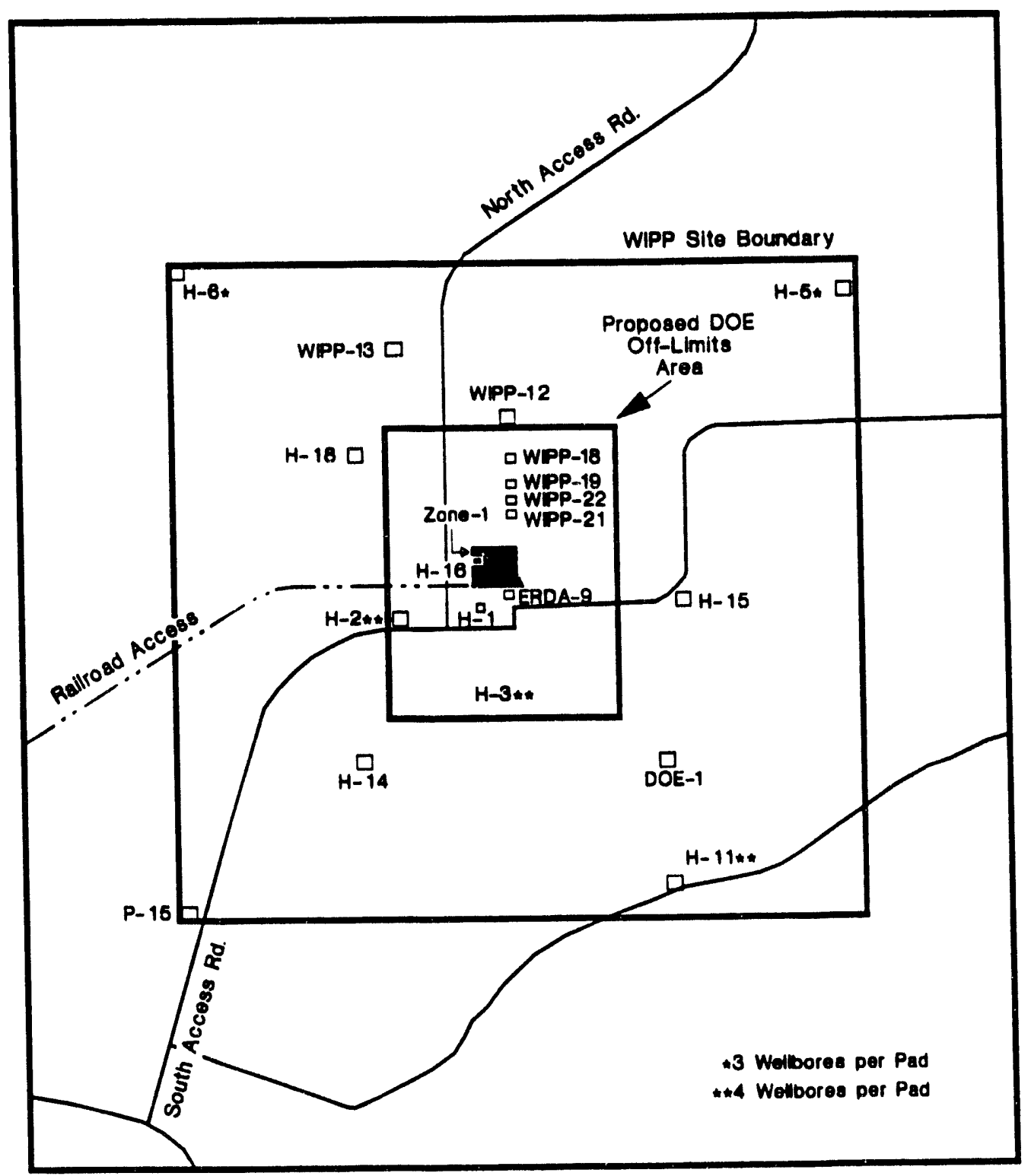

Figure 3.5 
The Rustler Formation groundwater underlying the withdrawal area has been sampled and analyzed at the WIPP site since 1985. This surveillance of groundwater will identify any existing and potential contamination sources. It should be noted that within this formation neither groundwater quality sampling nor hydrologic characterization efforts performed at the WIPP have identified any significant sources of potable groundwater beneath the WIPP site. To date, only zones of non-potable groundwater unfit for human consumption or agriculture purposes have been identified.

A zone of potable water has been identified beyond the southern border of the WIPP site in the Dewey Lake formation. It has been determined that locally recharged discontinuous lenses of perched, potable groundwater from this formation have produced useable quantities of water for drinking and agricultural purposes. (DOEMIPP 90-003). While Mercer (1983) indicates no conclusive evidence exists that such a zone is located within the WIPP site boundary, more recent studies suggests Dewey Lake groundwater along the southern boundary of the withdrawal area exists (Beauheim, 1987; Sanchez and McCasland, 1993). An exhaustive study of Dewey Lake groundwater recharge and transmissivity can be found in A.R. Lappin, 1989.

\subsubsection{Planned Actions}

Groundwater surveillance will continue at the WIPP as required by the Environmental Requlatory Guide for Radiological Effluent Monitoring and Environmental Surveillance, January 1991, DOE/HE-0173T. Should further applicable regulatory requirements be identified at a later date, surveillance programs will be adjusted accordingly.

In the event that a particular well is no longer needed for ground water surveillance, the well will be plugged and sealed in compliance with State and Federal regulations in effect at the time of abandonment. This procedure will apply as each DOE well (i.e., a well within the jurisdiction of the DOE or a well the DOE has assumed responsibility for) becomes abandoned until all such wells are plugged and sealed. Well pads and associated roads will be ripped, leveled, and reseeded with seed mixes reflecting indigenous plant species. 


\subsection{Salt Tailings}

\subsubsection{Objective}

DOE's objective is to manage the salt pile in an environmentally sound manner, until such time as a determination is made on the exact amount of salt to be returned to the underground for backfill purposes. The remaining salt will be disposed of under the Materials Act of 1947.

Salt from the underground mining operations is brought to the surface and stored in the bermed salt pile just north of the surface facilities. This salt storage pile contains 407,666 cubic yards, with a capacity to store the $2,116,402$ cubic yards of material projected to be excavated during the lifetime of the WIPP Project. Currently, there is also an inactive storage pile containing 162,103 cubic yards just east of the Exhaust Filter Building. This pile, referred to as the SPDV (Site and Preliminary Design Validation) pile, is a result of drilling one 12-foot diameter and one 6-foot diameter shaft to the repository depth of 2,150 feet. Added to the SPDV pile was the material from the excavation of the connecting and exploratory tunnels and four rooms excavated to the repository disposal room design dimensions. This activity was in support of the SPDV program (Figure 3.6). The DOE intends to relocate this material to the bermed salt pile for containment purposes.

\subsubsection{Planned Actions}

Salt from the stockpile which is not needed for backfill shall be disposed of under sections 2 and 3 of the Act of July 31, 1947 (30 U.S.C. 602, 603; commonly referred to as the "Materials Act of 1947 "). After disposal of the salt, the salt stockpile base will be ripped, leveled, mixed with soil, and reseeded with seed mixes reflecting indigenous plant species. 


\section{SALT TAILINGS PILES}

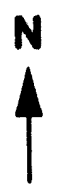

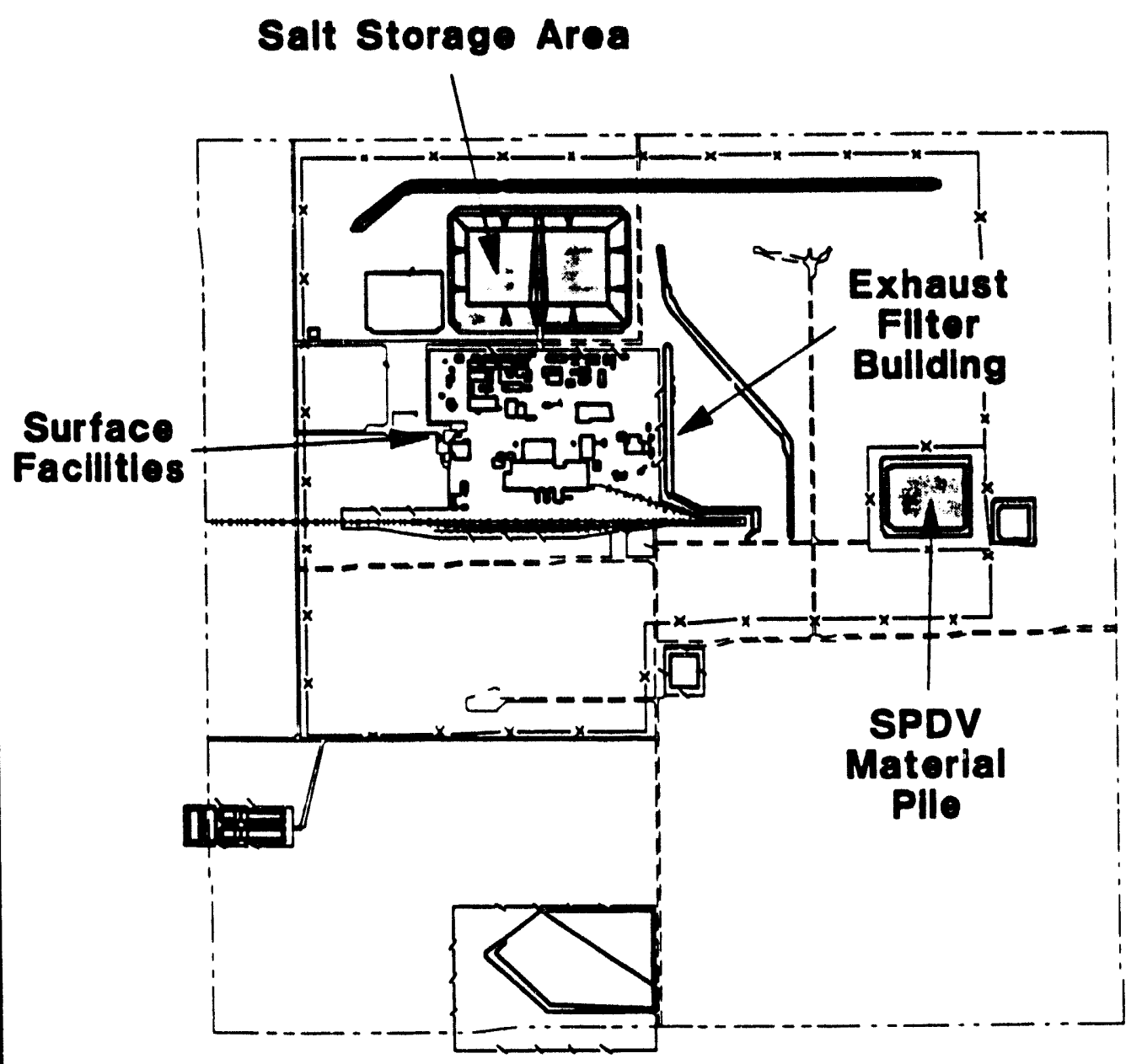

Figure 3.6 


\subsection{Beclamation}

\subsubsection{Obleative}

The objective of the DOE reclamation program is to return land disturbed by the WIPP activities to a stable ecological state, which will assimilate with the surrounding undisturbed ecosystem. These activities are intended to support the species of fauna and flora which were present before disturbance and to achieve control of above normal erosion. This will serve as a definition of a successful reclamation project. All reasonable and necessary steps will be taken by the DOE to ensure successful reclamation at the WIPP site.

\subsubsection{Planned Actions}

The DOE reclamation activities will be conducted in accordance with the Environmental Protection Implementation Plan (DOEMIPP 90-050); the Federal Land Policy and Management Act, 1976 - Public Law 94-579; the WIPP Final Supplement Environmental Impact Statement (DOE/EIS-0026-FS); the WIPP Final Environmental Impact Statement (DOE/EIS-0026); and applicable reclamation requirements contained in DOE Orders.

Upon completion of surface disturbing operations, the DOE will implement the following rehabilitation measures:

- Restoration of the existing landfill, caliche pits, mud pits, and their access roads will be accomplished by ripping, leveling, and reseeding with seed mixes reflecting indigenous plant species. If a pit is required for future use, restoration may be waived.

- Roads and pads constructed in conjunction with WIPP activities that are no longer needed will be restored by ripping, leveling, and reseeding with seed mixes reflecting indigenous plant species. 
If the WIPP site is abandoned for any reason, the DOE will comply with the following rehabilitation measures:

- Restoration of the existing landfill, caliche pits, mud pits, and their access roads will be accomplished by ripping, leveling, and reseeding with seed mixes reflecting indigenous plant species. If a pit is required for future use, restoration may be waived.

- Salt from the stockpile which is not needed for backfill will be disposed of under the Materials Act of 1947.

- The salt stockpile base shall be ripped, leveled, mixed with soil, and reseeded with seed mixes reflecting indigenous plant species.

- The stripping stockpile areas shall be ripped, leveled, mixed with soil, and reseeded with seed mixes reflecting indigenous plant species.

- Roads and pads constructed in conjunction with the WIPP will be ripped, leveled, and reseeded with seed mixes reflecting indigenous plant species.

- Fences constructed in conjunction with the project may be required to be removed.

- Decontamination, decommissioning, and abandonment of the surface facilities, including support facilities such as power lines, etc., and underground facilities will be done by the DOE in accordance with applicable laws, rules, and regulations in effect at the time. In the areas where surface facilities are removed, the areas will be ripped, leveled, mixed with soil, and reseeded with seed mixes reflecting indigenous plant species. 
DOE will seek review of proposed reclamation activities in advance by the BLM and appropriare State agencies to ensure compliance with applicable DOE reclamation commitments.

Rehabilitation of disturbed areas is an ongoing project at the WIPP site. These areas are identified, prioritized, and reclaimed as budgetary funding allows. 


\section{APPENDIX A}

\section{Consultation and Coordination}

This land management plan was developed in consultation with the public and others through a series of public meetings and through coordination with the varlous entitias as follows:

State of New Mexico

BLM, Carlsbad Resource Area

BLM, Roswell District Office

BLM State Office, Sante Fe, New Mexico

Environmental Evaluation Group, Albuquerque, Now Mexico

Eddy County Commissioners: January 19, 1993

Lea County Commissioners: January 14, 1993

Eddy County Scoping Meeting: January 25, 1993

Lea County Scoping Meeting: January 28, 1993

Lea County Public Information Meeting: July 21, 1993

Eddy County Public Information Meeting: July 22, 1993 


\section{APPENDIX 8}

\section{REFERENCES}

Beauheim, R.L.

1987. Intecoretations of Single-Well Hydraulic Teate Conduated Al and Neac the

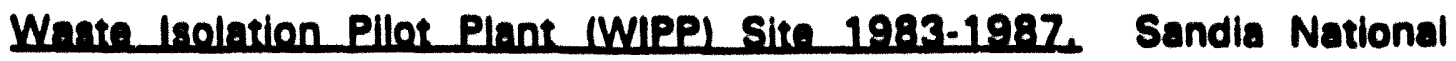
Laboratory Report, SAND 87-0037.

1987b Anslvais of Pumoina Tests of the Culebre Dolomite Conduated at the H-3 Hydropad at the Waste Laolation Pillot Plant_WIPPL Sandia National Laboratory Report, SAND86-2311.

Department of Interior, Bureau of Land Management

Carlsbad Resource Management Plan, Carlsbad, NM.

Department of Energy

1980 Einal Environmental Impact Statement (FEIS), October 1980. Waste Isolation Pilot Plant, DOE/EIS-0026.

1990 EinaL Supplement Envirenmental Impact Statement (FSEIS), January 1990. Waste Isolation Pllot Plant, DOE/EIS-0026-FS.

1992 Salt Impact Studies at the WIPP 1984-1990 (DOENWIPP 92-038).

Hicks, Patricia A.

1981a Mitiagtion of Four Archaeological Sites on the Waste lsolation Pilot Project near Carlsbad. New Mexice for Westinahouse Inc. Agency for Conservation Archaeology, Eastern New Mexico University, Portales, NM. 
$1981 \mathrm{~b}$ Mitioative Collection and Teating of Flve Archsedogalcal Sites on the Warte Inolation Pillot Prolect near Carlabad. New Mexico for Weatinahousen Ince. Agency for Conservation Archaeology, Eastern New Mexico University, Portales, NM.

Hunt, James E. and Robert J. Matrin

1989 Archaeological Clearance Repon for Dawson Geophysical Comoanv's Seiamic Teating Lines L- 1 and L-2 Slituated on Public Lands in Eddy Countv.NM Pecos Archeeological Consultants Report 89016, Carlsbad, NM.

1991 Archaeological Clearance Repon for Halliburton GSl's Selamic Lines No. 7194 Slituated on Public Lands in Lea and Eddy Counties. NM. Pecos Archaeological Consultants Report 91049, Carlsbad, NM.

Hunt, James E.

19928 Archaeological Clearance Report for Western Geophysical Comoany's Salsmic Testina Line No 2-3-32.4 Situated on Public Lands in Eddy County NM. Pecos Archeological Consultants Report 92094, Carlsbad, NM.

1992b Archaeological Clearance Report for Western Geophysical Company's Seismic Testing Line Nos, 2-3-32-5 and 2-3-32-7 Situated on Public Lands in Eddy County. NM, Pecos Archaeological Report 92096, Carlsbad, NM.

Lappin, A.R.

1989 Summary of Site Characterization Results at the WIPP Site. Southeastern New Mexice Sandia National Laboratory Report, SAND88-3278A.

Linnabery, Miles S.

1976 Appendix. In An Archaeological Reconnaissance of Sandia Laboratorias' Los Medanos Nuclear Waste Disposal Facility. Eddy County. New Mexice, by Jeffrey Nielsen, Agency for Conservation Archaeology, Eastern New Mexico University, Portales, NM. 
Lord, Kenneth J., and Williem E. Reynolds (editors)

1988 Archseological lnvestiastions of Three Sites within the WiPP Core Ares. Eddy County. New Mexice. Prepared for U.S. Army Corps of Engineers, Albuquerque District. Chambers Consultants and Planners, Albuquerque, NM.

MacLennan, Rodrick B. and Scott C. Schermer

1979 An Archasological Survev for the Waste Lsolation Pilot Prolect: Access Bosds and Railroad Right-of-Way. Agency for Conservation Archaeology Report 79-23, Eastern New Mexico University, Portales, NM.

Mariah Associates, Inc.

1987 Beport of Class II Survev and Testino of Cultural Resources at the WIPP Site at Carlabad. New Mexico. Prepared for U.S. Army Corps of Engineers, Albuquerque District, Albuquerque, NM.

Martin, Robert J.

1992 Archeeological Survev Beport for Western Geophysical Companv. Inc.'s Seismic Testing Line No. 2-3-32-6 Situated on Federa L Lands in Eddy County New Mexice. Pecos Archaeological Consultants Report 92093, Carlsbad, NM.

Nielsen, Jeffrey

1975 An ArchaeologicaL_Reconnaissance of Sandia Laboratories' Los Medanos Nuclear Waste Disposal Facility, Eddy County. New Mexico. Agency for Conservation Archaeology, Eastern New Mexico University, Portales, NM.

Sanchez, P.E. and McCasland, P.W.

1993 Assessment of Solid Waste Management Units, Supoertina Decumentation for WIPP RCRA Facility Assessment. NMEDMIPP 93-001, State of New Mexico/Department of Energy Agreement-in-Principle. 
Schermer, Scott C.

1978 Archaeological Clearance Report for Sandia Laboratories of 27 Miles of Seismic Corridor. Agency for Conservation Archaeology, Eastern New Mexico University, Portales, NM.

1980 A Report on the Archeological Site Locations in the WIPP Core Area with Mitigation Recommendations for Bechtel National, Inc. Agency for Conservation Archaeology Report 80-167, Eastern New Mexico University, Portales, NM.

1983 Report on Two Radiocarbon Dates Obtained from Feature 2. Site ENM 10233 on the WIPP Project Area near Carlsbad, New Mexico. On file with the Agency for Conservation Archaeology, Eastern New Mexico University, Portales, NM. 

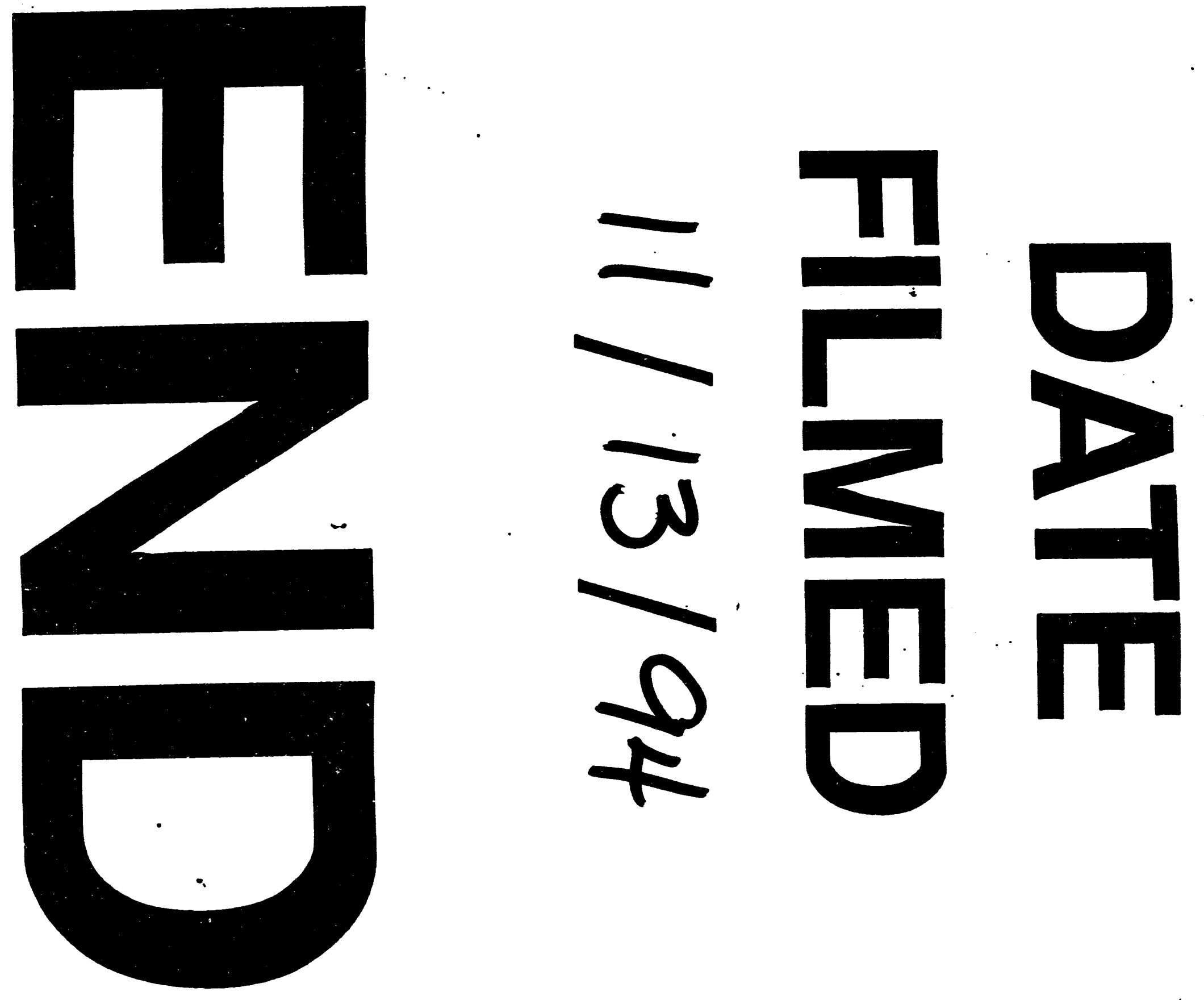
